\title{
Safrole and the Versatility of a Natural Biophore
}

\author{
Lima, L. M.*
}

Rev. Virtual Quim., 2015, 7 (2), 495-538. Data de publicação na Web: 31 de dezembro de 2014

\section{http://www.uff.br/rvq}

\section{Safrol e a Versatilidade de um Biofóro Natural}

Resumo: Safrol (1) obtido de óleos essenciais de diferentes espécies vegetais tem ampla aplicação na indústria química como precursor sintético do butóxido de piperonila, piperonal e de fármacos como a tadalafila, cinoxacina e levodopa. Do ponto vista toxicológico, é considerado uma hepatotoxina por mecanismo de bioativação metabólica conduzindo a formação de intermediários eletrofílicos, e tem sido descrito como inibidor de diferentes isoenzimas da família CYP450. A versatilidade de sua estrutura, permitindo várias transformações químicas, e a natureza biofórica de sua unidade benzodioxola ou metilenodioxifenila conferem-Ihe características singulares, que o tornam atrativo material de partida para a síntese de compostos com distintas atividades farmacológicas. Exemplos selecionados de compostos bioativos, naturais e sintéticos, contendo o sistema benzodioxola serão comentados, incluindo aqueles provenientes de contribuição específica do LASSBio ${ }^{\circledR}$.

Palavras-chave: Safrol; benzodioxola; metilenodioxi; CYP450; bióforo; compostos bioativos.

\begin{abstract}
Safrole (1), obtained from essential oils from different plant species, has wide application in the chemical industry as a synthetic precursor of piperonyl butoxide, piperonal and drugs such as tadalafil, cinoxacin and levodopa. From the toxicological point of view, it is considered a hepatotoxin through metabolic bioactivation, leading to the formation of electrophilic metabolites, and has been described as an inhibitor of different CYP450 isoenzymes. The versatility of its structure, allowing various chemical transformations, and the biophoric nature of its benzodioxole or methylenedioxy subunit, give it unique features and make it an attractive starting material for the synthesis of compounds with different pharmacological activities. Selected examples of natural and synthetic bioactive compounds containing the benzodioxole system will be discussed, including those from specific contribution of LASSBio ${ }^{\circledR}$.
\end{abstract}

Keywords: Safrole; benzodioxole; methylenedioxy; CYP450; biophore; bioactive compounds.

\footnotetext{
* Universidade Federal do Rio de Janeiro, LASSBio (http://www.farmacia.ufri.br/lassbio/) - Laboratório de Avaliação e Síntese de Substâncias Bioativas, Programa de Pesquisa em Desenvolvimento de Fármacos, Instituto de Ciências Biomédicas, PO Box 68024, CEP 21944-971, Rio de Janeiro-RJ, Brasil.

Mlidia@lassbio.icb.ufri.br DOI: $\underline{10.5935 / 1984-6835.20150023}$
} 


\title{
Safrol e a Versatilidade de um Biofóro natural
}

\author{
Lídia M. Lima* \\ Universidade Federal do Rio de Janeiro, LASSBio (http://www.farmacia.ufri.br/lassbio/) - \\ Laboratório de Avaliação e Síntese de Substâncias Bioativas, Programa de Pesquisa em \\ Desenvolvimento de Fármacos, Instituto de Ciências Biomédicas, PO Box 68024, CEP 21944- \\ 971, Rio de Janeiro-RJ, Brasil. \\ * lidia@lassbio.icb.ufri.br
}

Recebido em 3 de dezembro de 2014. Aceito para publicação em 3 de dezembro de 2014

\section{Physicochemical properties, natural sources and industrial applications}

2. Toxicity and metabolism

3. Role of cytochrome P450

4. 1,3-Benzodioxole in nature

5. Synthetic bioactive compounds

6. LASSBio's contribution

\section{Final remarks}

\section{Physicochemical properties, natural sources and industrial applications}

Safrole $\left(\mathbf{1}, \mathrm{C}_{10} \mathrm{H}_{10} \mathrm{O}_{2}\right)$, also known as safrol, 1,3-benzodioxole-5-(2-propenyl); $3,4-$ methylenedioxy-allylbenzene; 3-(3,4methylenedioxyphenyl)-prop-1-ene; 5allylbenzo[d][1,3]dioxole, is a colorless or slightly yellow liquid with boiling point 233.1 $\pm 30.0{ }^{\circ} \mathrm{C}$, density $1.118 \pm 0.06 \mathrm{~g} / \mathrm{cm}^{3}$ (at 20 ${ }^{\circ} \mathrm{C}$, 760 Torr), molar volume $145.0 \pm 3.0$ $\mathrm{cm}^{3} / \mathrm{mol}$ (at $20{ }^{\circ} \mathrm{C}, 760$ Torr) and molecular weight $162.19 \mathrm{~g} / \mathrm{mol}$. It is obtained by distillation of sassafras oil, currently derived from endangered plants of the Lauraceae family such as Ocotea pretiosa, Ocotea odorifera, Cinamomum petrophilum,
Cinamomum mollissimum and Sassafras albidum Nutt. ${ }^{1}$

Until 1960's Brazil was the major exporter of sassafras oil in the world, nowadays China and Vietnam are the great producers. The Ocotea pretiosa, a native tree in Mata Atlantica, typical from tropical rainforests, was the main store of the Brazilian sassafras oil until the depletion of this natural resource, placing it on the endangered list. Several others Lauraceae trees, which wood distillation was performed to yield a rich source of sassafras oil containing high amount of safrole, are also at risk of extinction. ${ }^{2-4}$

Many attempts to identify alternative natural sources from safrole have been made. Among then, the Piperaceae emerge as a promising alternative. First described by 
Yunker in 1972, ${ }^{1}$ Piper hispidinervium (known as long pepper) is a safrole-rich plant well distributed throughout South America and endemic in the state of Acre in Brazil. Its unique conditions for cultivation in areas with facilities for harvest, associated with high levels of safrole in its leaves, make the sustainable management and its economic exploration feasible. Others Piper species, including $P$. divaricatum $P$. nigrum, $P$. callosum and $P$. aduncum are also considered eventual sustainable source of safrole. ${ }^{4,5}$

Historically, the demand for sassafras oil depends mainly on the international market for piperonyl butoxide (PBO, 2), a semisynthetic derivative of safrole, that is a crucial component in the natural pyrethroid insecticides, due its synergist activity, and for heliotropin (3), used in flagrances and as flavoring agent (Figure 1). ${ }^{4,5}$

The finding that heliotropin or piperonal (3), easily synthesized from safrole ${ }^{6-8}$ (Figure 2), was a key intermediate in the synthesis of complex organic molecules expanded its value and its industrial application. In fact, $\mathbf{3}$ can be used as starting material from the synthesis of several biological active compounds, including the drugs cinoxacin (5), tadalafil (6) and levodopa (7) (Figure 2). It is also used in the synthesis of illicit drug 3,4methylenedioxy- $N$-methylamphetamine (MDMA, ecstasy, 8).

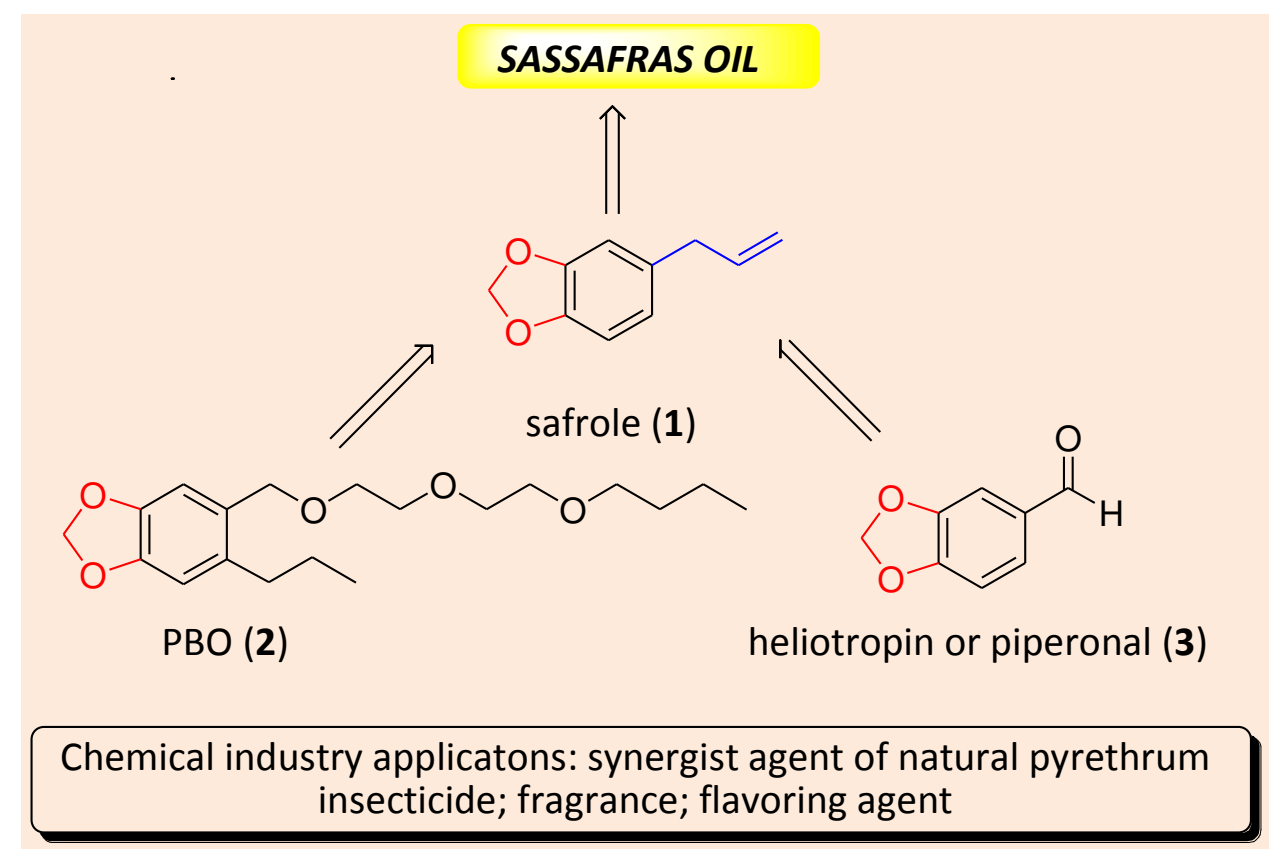

Figure 1. Safrole (1) a raw material for the synthesis of PBO (2) and heliotropin (3) 


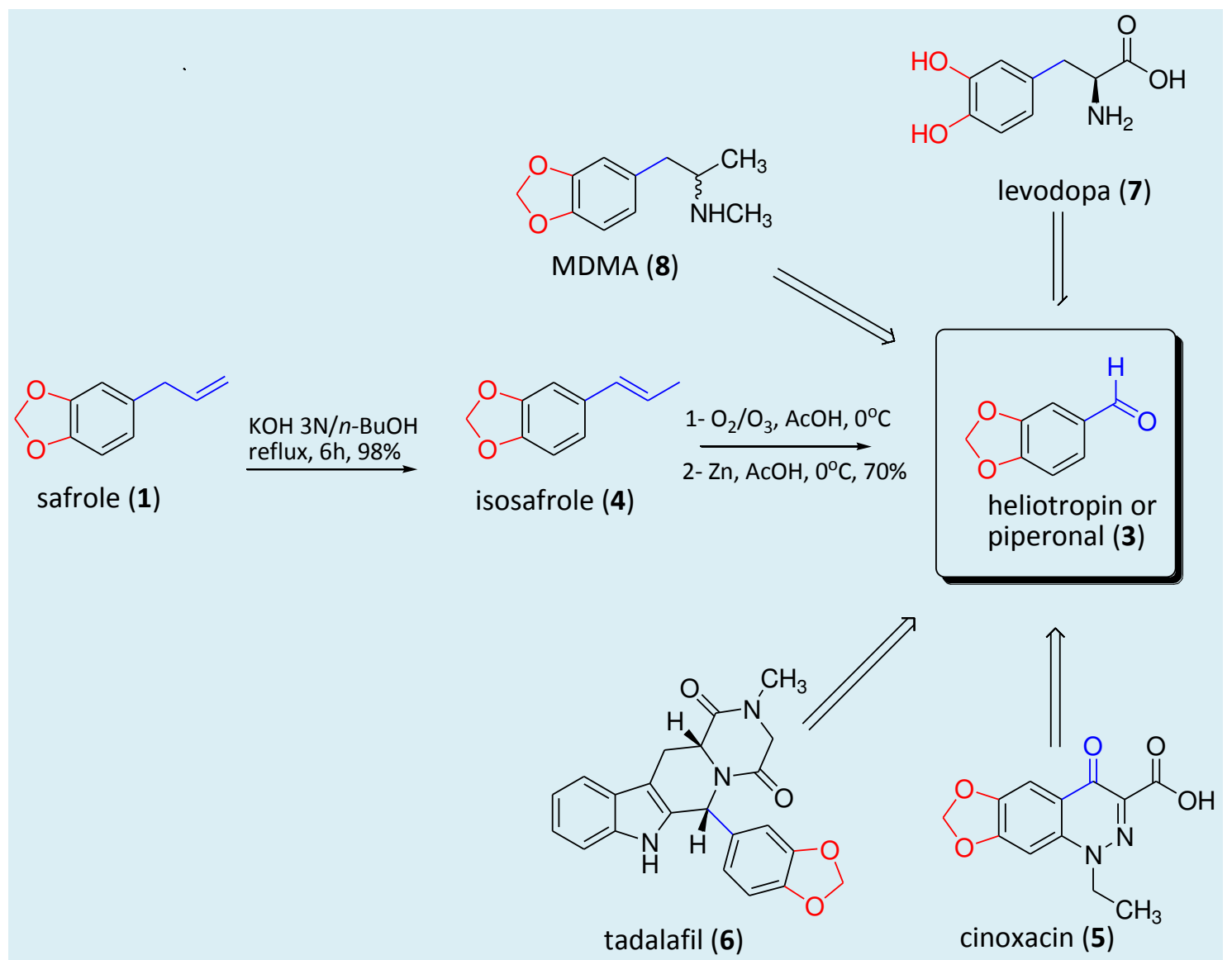

Figure 2. Heliotropin (3) obtained from safrole (1) and its use as raw material for the synthesis of cinoxacin (5), tadalafil (6), levodopa (7) and MDMA (8)

\section{Toxicity and metabolism}

The most important dietary sources of safrole (1) are nutmeg, mace and its essential oils, although it is also a natural constituent of cinnamon, anise, black pepper and sweet basil and is present in cola drinks. ${ }^{9,10}$ Safrole (1) was first recognized to be a hepatocarcinogen in the 1960's and many animal studies have been documented concerning this toxicology. ${ }^{11-15}$

Several attempts to explain safrole's muta- and genotoxicity have been made. In general, all hypotheses predict its bioactivation to produce electrophilic intermediates that are able to interact with DNA. ${ }^{14-18}$ This bioactivation process is dependent of previous oxidative reactions catalyzed by different isoenzymes of cytochrome P450 (CYP450) family (Figure 3). In the first hypothesis, the allyl double bond of safrole (1) is oxidized to epoxide metabolite (9), which can alkylate DNA (10). This hypothesis is considered less likely, since metabolite $\mathbf{9}$ is fast hydrolyzed by microsomal epoxide hydrolase. ${ }^{14,16}$ The most well-established hypothesis is based on the reactivity of methylene $\left(\mathrm{C1}^{\prime}\right)$, both allylic and benzylic, presented in the alkyl side chain of safrole (1). ${ }^{14,17}$ This position is easily oxidized to $\mathbf{1}^{\prime}$-hydroxy derivative (11), by a classical CYP450 mediated hydroxylation. This metabolite (11) undergoes phase-2 metabolism by sulfotransferase (SULT), that catalyze the transfer of a sulfonate group ($\mathrm{SO}^{3-}$ ) from the cofactor $3^{\prime}$ phosphoadenosine-5'-phosphosulfate (PAPS) to the hydroxyl group of 11, to furnish the metabolite 12 (Figure 3$)^{18}$. This reactive metabolite can interact with DNA by a 
classical $\mathrm{SN}_{2}$ reaction, eliminating sulfate ion $\left(\mathrm{SO}^{4-}\right)$ and forming a covalent adduct of this essential macromolecule (13). An alternative mechanism is also possible and provides the loss of $O$-sulphate, resulting in a stabilized carbonium ion that form adducts with DNA and may be assumed to play a role in tumorigenesis. ${ }^{19-22}$ The third hypothesis is based on the bioactivation of safrole (1) by $O$ dealkylation step of methylenedioxy subunity. The $O$-dealkylation process, catalyzed by CYP450 enzymes and which mechanism was elucidated by Fukuto and coworkers (1991), ${ }^{23}$ furnish the catechol metabolite (14). This metabolite can undergoes oxidation of 1 or 2 electrons to provide the ortho-semiquinone (15) or orthoquinone (16), respectively, generating reactive oxygen species that can promote oxidative DNA damage (Figure 3). The quinones are electrophiles as well as redoxactive compounds and, therefore, have been implicated as the ultimate cytotoxins formed from the oxidative metabolism of numerous aromatic compounds. ${ }^{24}$ The $o$-quinone (16) undergoes nonenzimatic isomeration in order to produce the tautomer $\mathbf{1 7}$. This highly electrophilic $p$-quinone-methyde (17) is able to form covalent bond with bionucleophiles and consequently is able to alkylate the DNA. $^{25}$

\section{Role of cytochrome P450}

Besides the central role of CYP450 in the bioactivation of safrole (1), ${ }^{26,27}$ discussed in the previous section, this enzyme complex plays an important role in the biosynthesis of 1,3-benzodioxole function or 1,3- methylenedioxy bridge. As demonstrated by Clemens and Barz (1995), ${ }^{28}$ the microsomal preparations from elicited heterotrophic cell cultures of chickpea in the presence of $\mathrm{O}_{2}$ and NADPH catalyze methylenedioxy bridge formation (21 and 22) from pratensein (19) and calycosin (20) (Figure 4). They also demonstrated that methylenedioxy bridge formation, in these conditions, was blocked by various CYP450 inhibitors, characterizing a cytochrome P450-dependent process. ${ }^{28}$

CYP450 enzymes have been shown to play essential roles in plant secondary metabolism, ${ }^{29}$ and all members of the CYP719A subfamily, that have been characterized so far, catalyze methylenedioxy bridge formation in isoquinoline alkaloid biosynthesis. ${ }^{30}$ As exemplified in Figure $5,(S)$ scoulerine (23) are converted at (S)cheilanthiofoline (24) and (S)-stylopine (25) by methylenedioxy bridge formation from hydroxy-methoxyphenyl subunit catalyzed by CYP719A. ${ }^{31}$

CYP450-dependent enzymes are also implicated in the biosynthesis of protoberberine alkaloids in the Papaveraceae family of plants. Their immediate biosynthetic precursor is (S)-reticuline (26). Its conversion into berberine (29) requires oxidative cyclization catalyzed by berberine bridge enzyme (BBE) to furnish (S)-scoulerine (23), followed by its $O$-methylation to obtain (S)-tetrahydrocolumbamine (27) (Figure 6). As an integral step in the biosynthesis of $\mathbf{2 9}$, the methylenedioxy bridge is formed from intermediate $\mathbf{2 7}$ by CYP719A13 catalyst, yielding $(S)$-canadine (28), that is oxidized to berberine (29) by (S)tetrahydroprotoberberine oxidase (STOX) (Figure 6). ${ }^{32,33}$ 
<smiles>[O-][N+]([O-])([O-])C(O)Cc1ccc2c(c1)OCO2</smiles>

(10)<smiles>C=CC(O[Na])c1ccc2c(c1)OCO2</smiles>

(13)

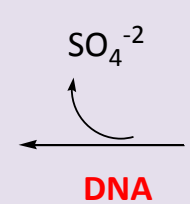

DNA<smiles>C=CC(OS(=O)(=O)[O-])c1ccc2c(c1)OCO2</smiles>

(12)<smiles>c1cc2c(cc1CC1CO1)OCO2</smiles>

(9) CYP2A6, 2E1,
2C9, 2D6, 1A2

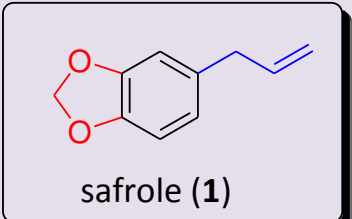

CYP2A6, 2E1, 2C9, $2 \mathrm{D} 6$

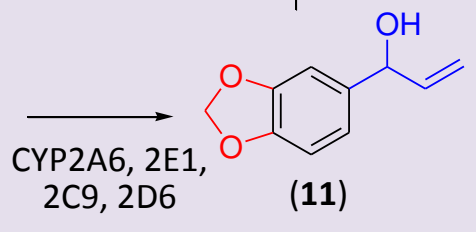

CYP2A6, 2E1, 2C9, 2D6, 1A2<smiles>C=CCc1ccc(O)c(O)c1</smiles>

(14)

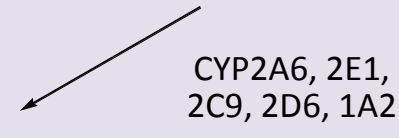

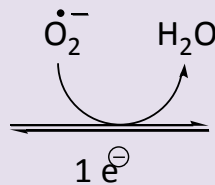

,<smiles>C=CCc1ccc(O)c([O-])c1</smiles>

(15)

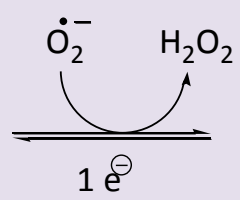

DNA
(18)<smiles>O=C1C=CC(=CCC[N+](=O)[O-])C=C1O</smiles>

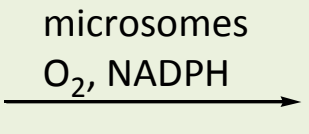<smiles>[R]c1cc(O)cc2occ(-c3ccc4c(c3)OCO4)c(=O)c12</smiles>

$$
\begin{aligned}
& \mathrm{R}=\mathrm{H}(21) \\
& \mathrm{R}=\mathrm{OH}(22)
\end{aligned}
$$

Figure 4. Methylenedioxy bridge formation from pratensein (19) and calycosin (20) in a cytochrome P450-dependent process 


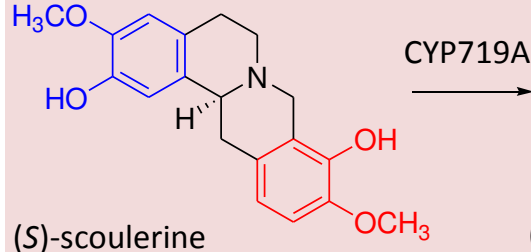

(23)

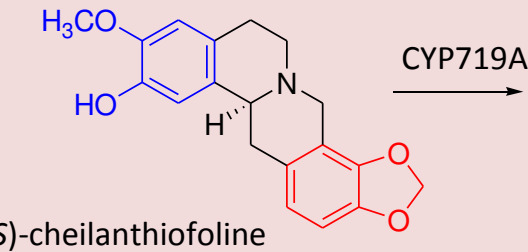

(24)

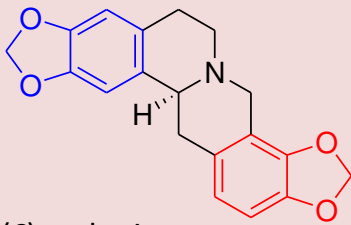

(S)-stylopine

(25)

Figure 5. Methylenedioxy bridge formation from $(S)$-scoulerine (23) to form (S)cheilanthiofoline (24) and (S)-stylopine (25)<smiles>COc1ccc(C[C@@H]2c3cc(O)c(O)cc3CCN2C)cc1O</smiles>

(26)

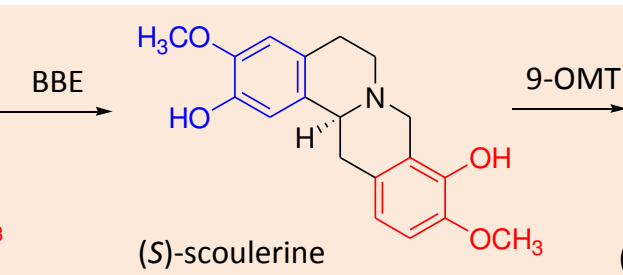

(23)

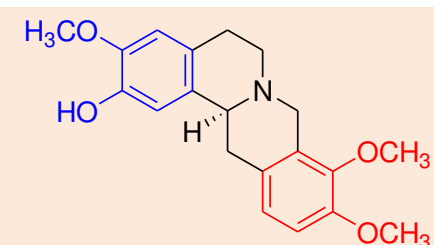

(S)-tetrahydrocolumbamine

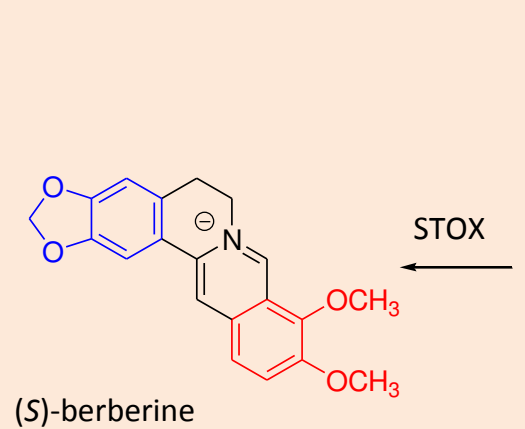

(29)
(27)

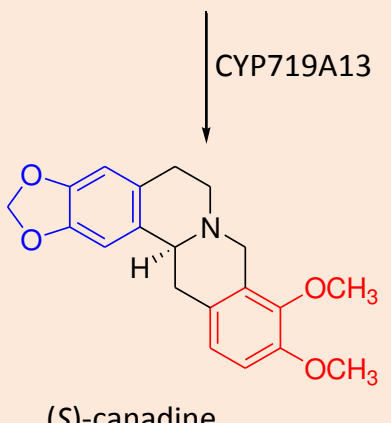

(S)-canadine

(28)

Figure 6. Methylenedioxy bridge formation a key step in the biosynthesis of berberine (29) from (S)-reticuline (26)

Compounds having 1,3methylenedioxyphenyl or 1,3-benzodioxole subunit frequently elicit several different effects on CYP450-mediated pathways of drug oxidation in mammals and other species. It has been clearly established that these compounds inhibit the activity of CYP450 enzymes in a number of target species in vivo and in microsomal fractions in vitro. Considering that they also can be a substrate for CYP450 enzymes, is possible that this kind of inhibition may be due to a competitive mechanism. However, microsomal fractions incubated with piperonyl butoxide (PBO, 2) and NADPH showed decrease in CYP450 content, suggesting that the mechanism of inhibition was more complicated. Unusual Soret absorbances near 427 and $455 \mathrm{~nm}$ were detected in microsomal spectra during such incubations, proposing that 1,3-benzodioxole oxidation generate a metabolite-CYP450 complex that contribute to the observed decline in CYP450 content and in xenobiotic oxidation. $^{34,35}$

The nature of metabolite involved in the complexation of CYP450 and benzodioxole derivatives remains unclear. Several possible intermediates have been suggested. ${ }^{36}$ Among then, formation of a carbene at the methylene carbon atom of methylenedioxy bridge receives most current support (Figure 7). ${ }^{36-38}$ This active intermediate form an stable $\mathrm{Fe}$ (II)-carbene bond and, therefore, cannot be dissociated by treatment with lipophilic chemicals or drugs. Nevertheless, Fe(III)- 
carbene complex can be displaced and once ability and monooxygenase activity. ${ }^{36}$ dissociated restores microsomal CO-binding

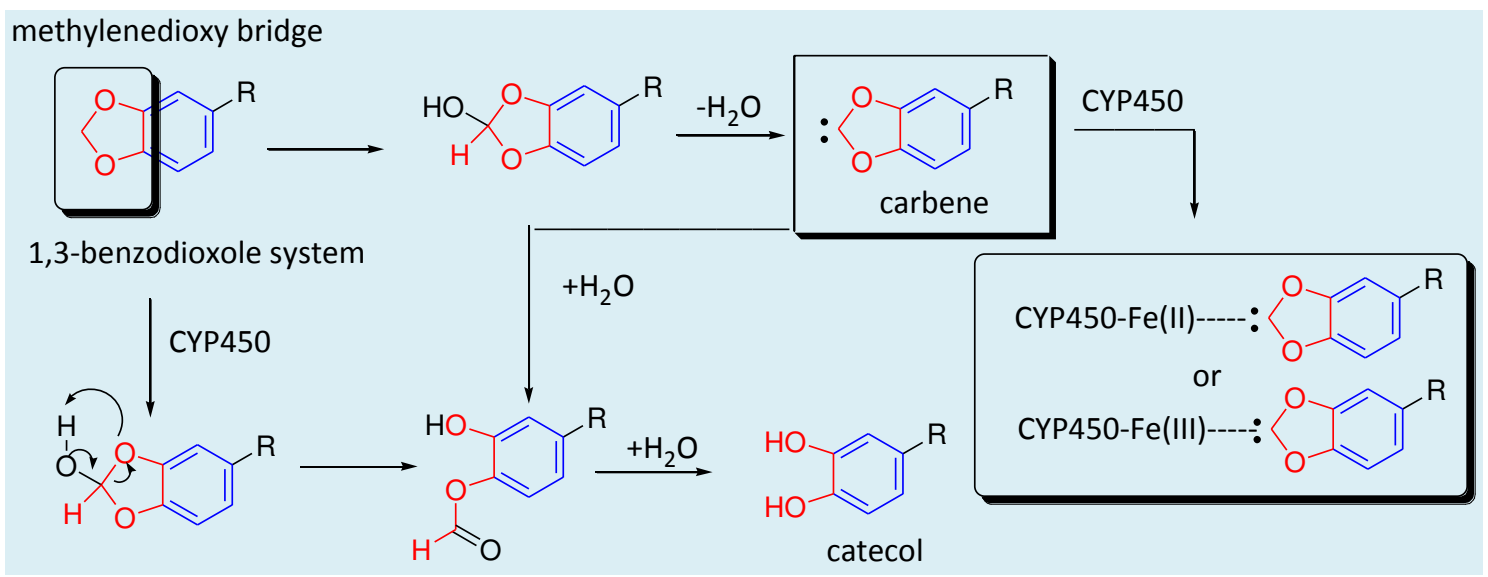

Figure 7. Oxidation of 1,3-benzodioxole subunit generating a hypothetic carbene intermediate able to form stable complex with CYP450 enzymes inhibiting their enzymatic activity

Paroxetine (30), a psychotropic drug used in patients with depression, schizophrenia or sleep disorder, was demonstrated to be a CYP450 inhibitor. It exhibited a mixed-type inhibition (competitive and non-competitive) toward mexiletine $p$-hydroxylation in human liver microsomes, in a mechanism-based inactivation that seems to involve carbeneCYP450 complex (Figure 8). ${ }^{39}$

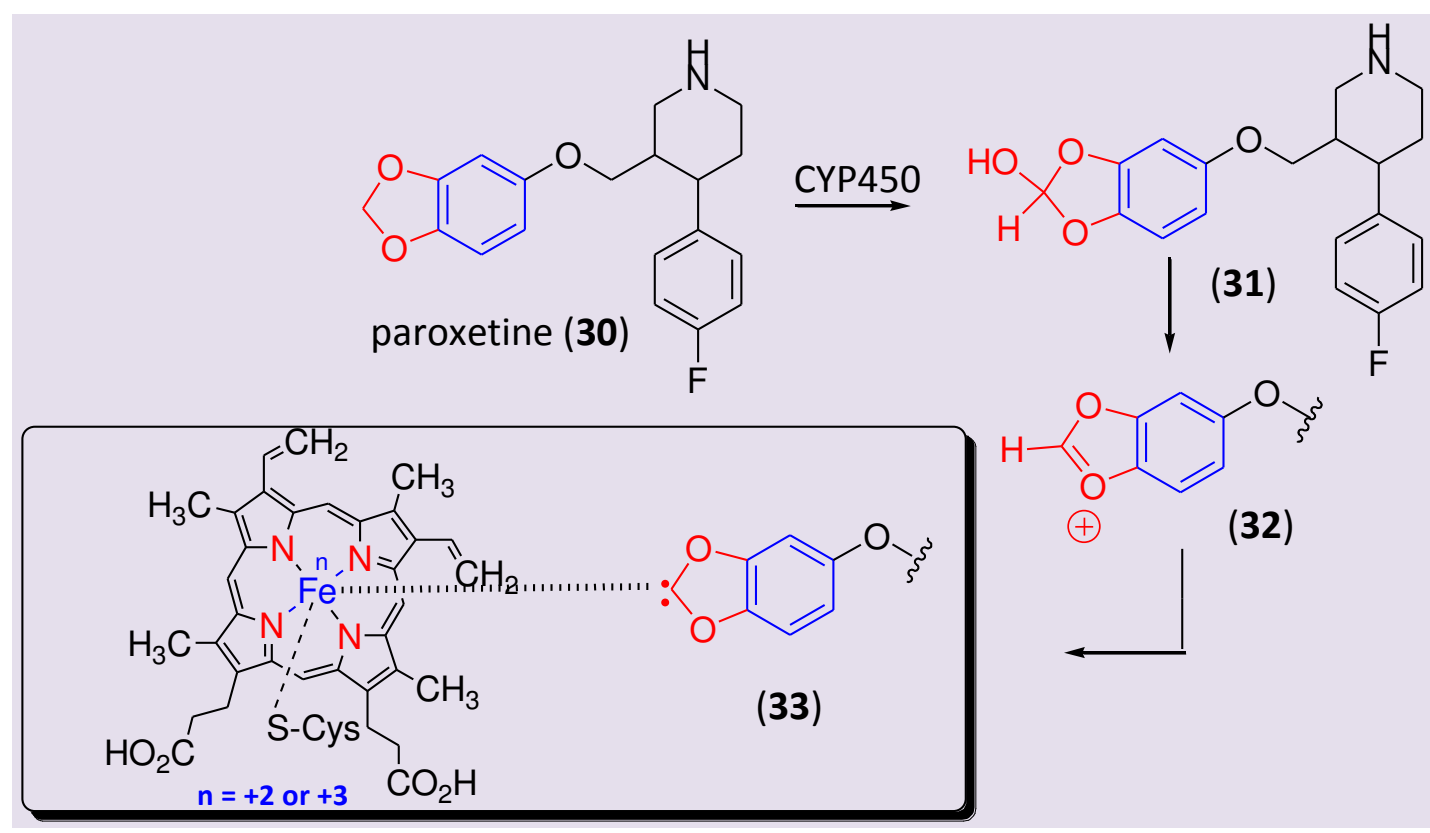

Figure 8. CYP450 inhibition by carbene-CYP450 complex (33) formed from oxidation of 1,3benzodioxole subunit of paroxetine (30)

Zamifenacin (UK-76,654; 34), an M3 muscarinic receptor antagonist that selectively inhibits intestinal motility, was proposed for the symptomatic treatment of 
irritable bowel syndrome in man. Due to occasional moderate but reversible transaminase elevations in early clinical trials, its clinical development was suspended by Pfizer. The hepatic toxicity seems to be dependent of the animal species and related to the metabolites generated by methylenedioxy oxidation catalyzed by CYP450 enzymes. Cytotoxicity of zamifenacin (34) and its two major metabolites (35 and 36) against primary hepatocytes from rat, dog and monkey was studied. Canine hepatocytes were most sensitive to UK76,654 (34) cytotoxic effect, while all three hepatocyte types were sensitive to the metabolite UK-82,201 (36) within only a few hours of initial exposure to this metabolite (Figure 9). ${ }^{40,41}$ Despite the structure similarity with paroxetine (30) and their common metabolism pathway, the ability of zamifenacin (34) to inhibit CYP450 activity has not been studied.

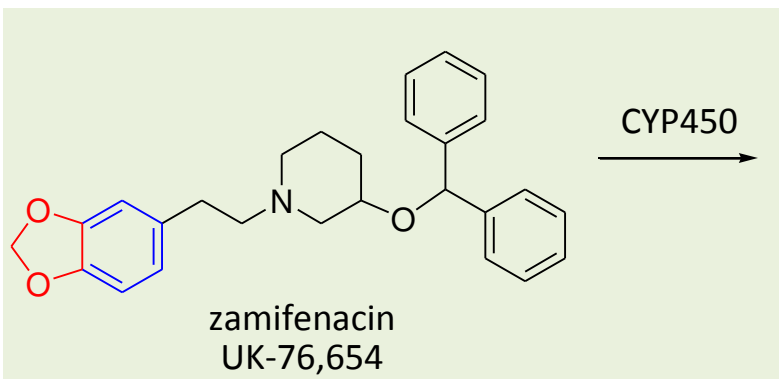

(34)<smiles>CC(C)(C)OC(=O)c1ccc(CCCN2CCCC(OC(c3ccccc3)c3ccccc3)C2)cc1O</smiles>

(35)<smiles>[R16][R6]([H])([H])[H]</smiles>

(36)

Figure 9. CYP450 dependent metabolism of 1,3-benzodioxole subunit of zamifenacin (34) to obtain the metabolite $\mathbf{3 5}$ and its phase- 2 metabolite $\mathbf{3 6}$ by methylation catalyzed by cathecol $O$-methyltransferase (COMT)

Safrole (1) is also a non-selective inhibitor of human CYP450, being able to inhibit the catalytic activity of CYP1A2, CYP2E1, CYP2A6, CYP2D6 and CYP3A4. The in vitro effects of safrole (1) on human CYP450 enzymes (CYPs) were studied using Escherichia coli-expressed bicistronic human CYPs. The $\mathrm{IC}_{50}$ values of safrole for CYPs isoenzymes were in the order CYP2E1 $(1.7 \pm 0.8 \mu \mathrm{M})<$ CYP1A2 $(5.7 \pm 0.9$ $\mu \mathrm{M})<$ CYP2A6 $(12.0 \pm 0.5 \mu \mathrm{M})$ CYP3A4 $(43.5 \pm 8.5 \mu \mathrm{M})<$ CYP2D6 $(110 \pm 12$ $\mu \mathrm{M}){ }^{42}$

CYP6D1, a CYP isoenzyme responsible for pyrethroid resistance in the Learn-PyR (LPR) strain of house fly, was demonstrated to be inhibited by several 1,3-benzodioxole derivatives, mainly by piperonyl butoxide (PBO, 2). As a consequence, in the LPR strain, PBO (2) can enhance the toxicity of the pyrethroid insecticide permethrin 130-fold, which could explain the insecticide synergist activity of this safrole derivative. ${ }^{43}$

\section{1,3-Benzodioxole in nature}

1,3-Benzodioxole subunit is well distributed in nature. It can be found in the structure of several secondary metabolites of 
plants. Safrole (1) is the simplest natural 1,3benzodioxole derivative and, as previously mentioned, can be found as constituent of essential oil from different plant species. However, as exemplified in Figure 10, more complexes structures containing 1,3benzodioxole system can also be also found and includes lignans, flavonoids, isoflavonoids, alkaloids, and so on. ${ }^{44-50}$<smiles>COc1cc2c(-c3ccc4c(c3)OCO4)c3c(c(OC)c2c(OC)c1OC)COC3=O</smiles>

5-methoxyjusticidin A (37)<smiles></smiles>

podophyllotoxin (38)

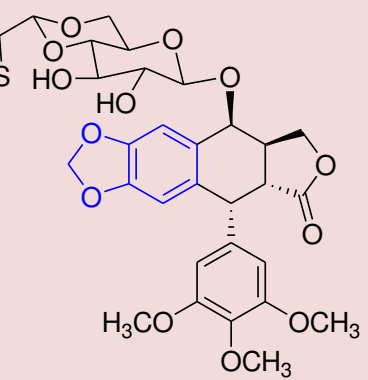

teniposide (39)<smiles>c1cc2c(cc1[C@@H]1OC[C@@H]3[C@H](c4ccc5c(c4)OCO5)OC[C@H]13)OCO2</smiles>

sesamin (40)

\section{FLAVONOIDS/ISOFLAVONOIDS}<smiles>C=C(C)C1Cc2cc3c(cc2O1)oc(=O)c1c2cc4c(cc2oc31)OCO4</smiles>

\section{ALKALOIDS}<smiles>COc1ccc(C(=O)Cc2c(CCN(C)C)cc3c(c2O)OCO3)c(C(=O)O)c1OC</smiles>

narceine (45)<smiles>CN1CCc2cc3c(cc2C1[C@@H]1OC(=O)c2c1ccc1c2OCO1)OCO3</smiles>

bicuculline (46)<smiles>COc1cccc2c1C[C@@H]1C2=C2C(=CC3=C2OCO3)CCN1C</smiles>

stephanine (47)

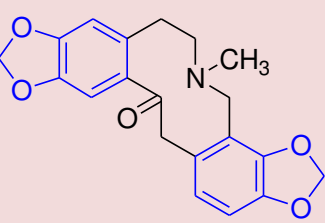

protopine (48)

Figure 10. Examples of natural products containing 1,3-benzodioxole subunit

Among compounds exemplified in Figure 10 , teniposide (39) is noteworthy. It's a semisynthetic lignin derivative approved by FDA as antitumor drug. It acts by inhibiting topoisomerase II, therefore, preventing DNA synthesis and hence replication. In clinical it has been used in association to treat pediatric patients with poor prognosis of acute lymphocytic leukemia. ${ }^{51}$

Combretastatin A-2 (49, Figure 11) is also an important example of natural benzodioxole derivative. This rare Z-stilbene family of plant biosynthetic products is a key antineoplastic and cancer vascular targeting isolated from the South African bush willow tree Combretum caffrum. ${ }^{52}$ 


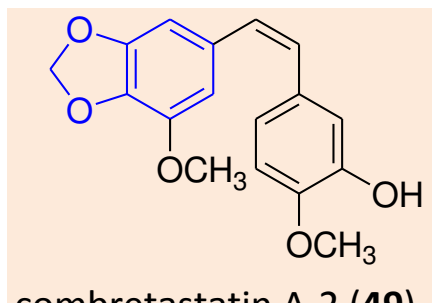

Figure 11. Structure of the natural Z-stilbene benzodioxole derivative combretastatin A-2 (49)

Guineensine (50, Figure $\mathbf{1 2})$ is a natural benzodioxole-alkenyl- $N$-isobutylamide derivative isolated from Piper nigrum. As described by Nicolussia and coworkers (2014), ${ }^{53}$ guineensine (50) is a new nanomolar inhibitor $\left(\mathrm{EC}_{50}=290 \mathrm{nM}\right)$ of cellular uptake of the endocannabinoid anandamide, through a mechanism of action that doesn't involve inhibition of endocannabinoid degrading enzymes such as fatty acid amide hydrolase (FAAH) or monoacylglycerol lipase (MAGL). Despite its ability to induce cannabimimetic effects in BALB/c mice, such as catalepsy, hypothermia and analgesia activity, it is not able to interact with cannabinoid receptors or fatty acid binding protein 5 (FABP5), a major cytoplasmic AEA carrier, revealing an intriguing mechanism of action that should be better elucidated. ${ }^{53}$<smiles>CC(C)CNC(=O)/C=C/C=C/CCCCCC/C=C/c1ccc2c(c1)OCO2</smiles>

Figure 12. Structure of the natural benzodioxole-alkenyl- $N$-isobutylamide guineensine (50) isolated from Piper nigrum

The new benzodioxole neolignan (+)kunstlerone (51, Figure 13), isolated from Beilschmiedia kunstleri, was first described by Mollataghi and coworkers in 2011. ${ }^{54}$ This compound showed similar radical scavenging ability than ascorbic acid, determined in DPPH radical assay.<smiles>C=CCCCCCOc1ccc2c(c1)OCO2</smiles>

Figure 13. Structure of (+)-kunstlerone (51) a new benzodioxole neolignan isolated from Beilschmiedia kunstleri

Studying the bicyclo[3.2.1]octanoid neolignans from leaves of Ocotea macrophylla Kunth, Coy-Barrera and coworkers $(2009)^{55}$ were able to identify a new neolignan called ocophyllol A (52, Figure 14). The PAF-antagonistic activity of $\mathbf{5 2}$, was 
investigated testing the ability of ocophyllol A to inhibit PAF-induced aggregation on rabbit platelets. In this model, ocophyllol A (52) showed IC $C_{50}$ value of $3.1 \mu \mathrm{M}$. $^{55}$

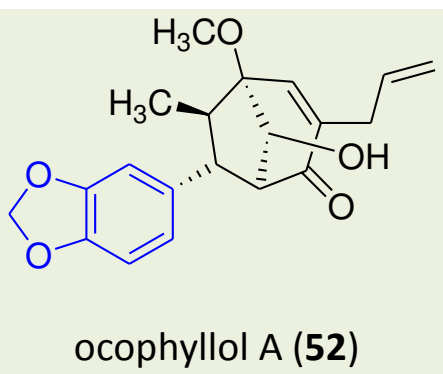

Figure 14. Structure of ocophyllol A (52) a new benzodioxole neolignan with PAF-antagonistic activity

1,3-Benzodioxole system is also present in structure of secondary metabolites from marine sources. An exceptional example can be illustrated by ecteinascidin 743 (Et743, 53), a complex alkaloid derivative isolated from Ecteinascidia turbinate. Despite the promise antitumor activity Et-743 (53) the viability of clinical trial studies was compromised, due its very low yield from natural sources. To overcome this limitation, a semi-synthesis was proposed by PharmaMar chemists exploring safracin B, from the marine Pseudomonas fluorescens, as raw material (Figure 15). The semisynthesis was realized in 21 steps, providing enough amount of Et-743 (trabectedin, 53) for clinical trials. This compound (53) was approved by EMEA and FDA, under the brand name Yondelis, for the treatment of sarcoma and ovarian cancer. ${ }^{56-58}$

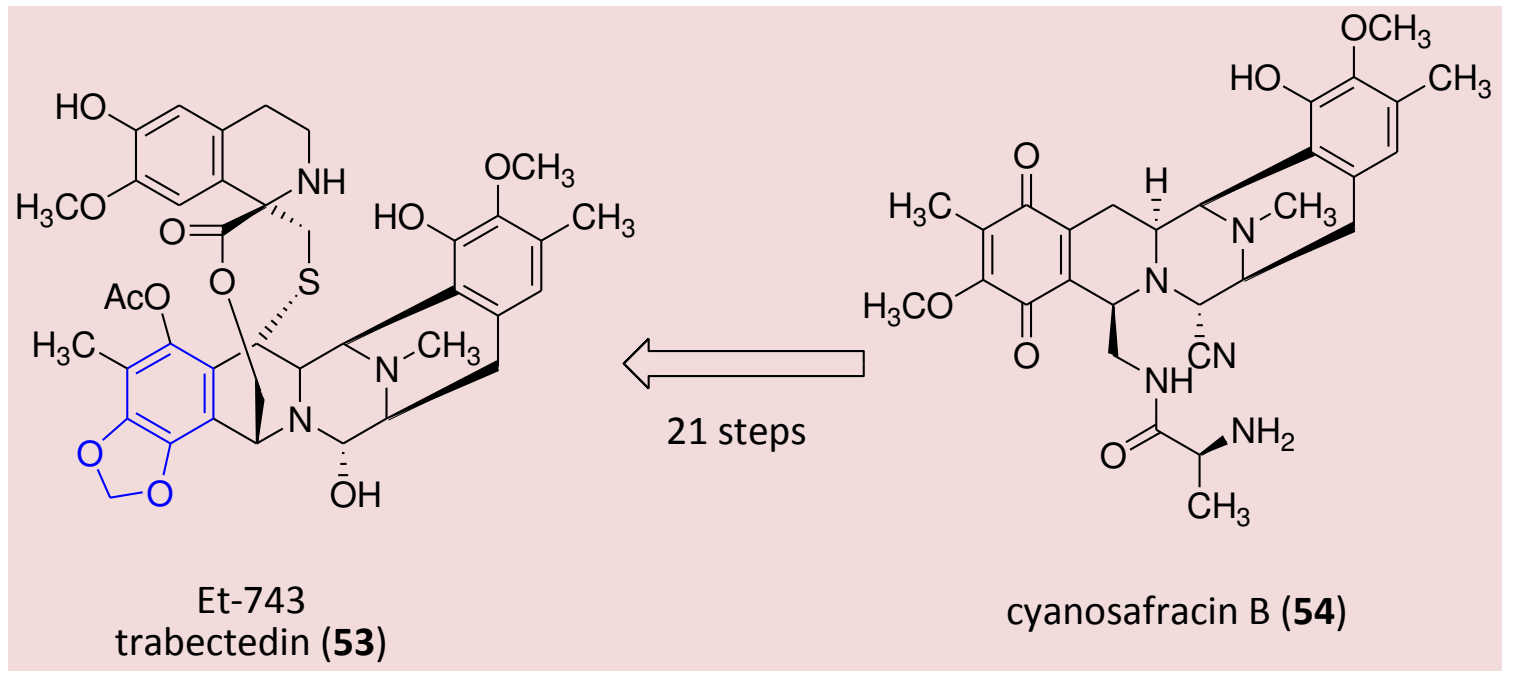

Figure 15. Et-743 (53) and it semi-synthetic precursor 54

\section{Synthetic bioactive compounds}

The peculiar reactivity of safrole permits the selective modification of each functional group that compose its structure, ${ }^{59}$ making it an attractive raw material for the synthesis of several biological compounds. 
From the medicinal chemist's point of view, the 1,3-benzodioxole is a versatile biophore, which can be recognized by different bioreceptors, through hydrogen bond and/or hydrophobic interaction. These features make 1,3-benzodioxole system a common molecular fragment or scaffold in the structure of various synthetic bioactive compounds, as exemplified by the following examples.

Searching for melanin-concentrating hormone receptor $(\mathrm{MCHr})$ antagonists as a strategy for anti-obesity pharmacotherapy, Lynch and coworkers $(2006)^{60}$ described the optimization of a series of chromone-2carboxamide derivatives and their assessment of potency, efficacy, and cardiovascular safety. From this study compound 55 (Figure 16) was demonstrated to be a potent $\mathrm{MCHr}$ antagonist $\left(\mathrm{IC}_{50}=\right.$ $0.003 \mu \mathrm{M})$, able to induce dose-dependent weight loss in mouse model upon oral administration. Later, this compound was demonstrated to have dose-dependent QT interval prolongation in a pentobarbitalanesthetized dog model, related to functional blockade at the hERG (human Ether-a-go-go Related Gene; IC $C_{50}=15.1 \mu \mathrm{M}$ ), and was also demonstrated to inhibit CYP3A4 with $\mathrm{IC}_{50}=$ $23.5 \mu \mathrm{M} .{ }^{61}$ These results committed the following studies with this 1,3-benzodioxole bioactive compound.

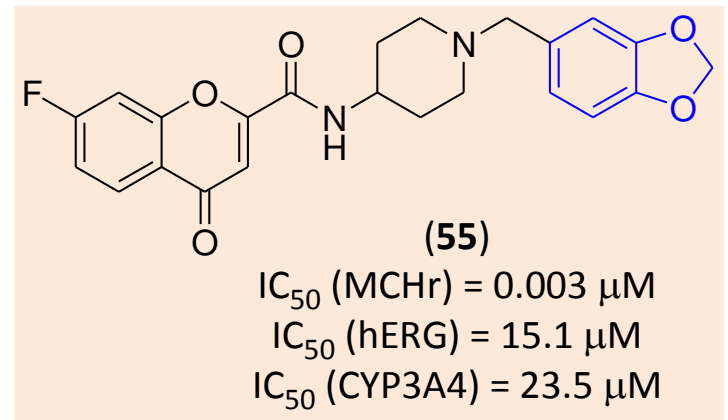

Figure 16. Structure of the melanin-concentrating hormone receptor $(\mathrm{MCHr})$ antagonist (55) and its potency against MCHr, hERG and CYP3A4

GYKI 53784 (LY303070; 56, Figure 17) is a selective and non-competitive antagonist at alpha-amino-3-hydroxy-5-methyl-4-isoxazolepropionate (AMPA) receptors, belonging to the 2,3-benzodiazepine class containing benzodioxole framework. It is considered to be a lead drug candidate for the treatment of epilepsy, schizophrenia and neuro degenerative disorders. ${ }^{62}$

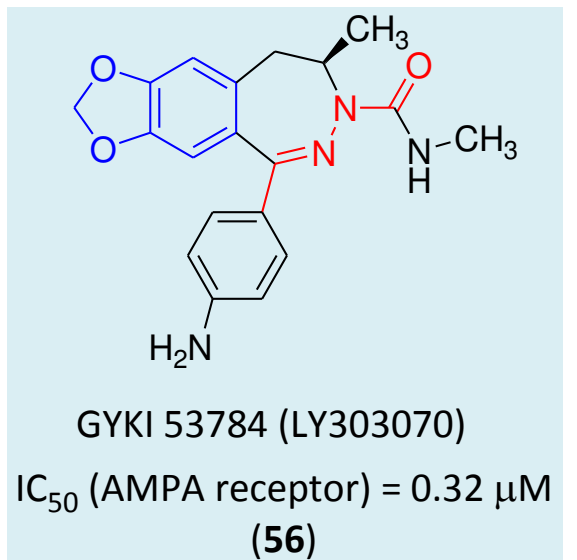

Figure 17. Structure of GYKI 53784 (56) a non-competitive antagonist of AMPA receptors 
Considering that AMPA receptor antagonists could serve as therapeutically useful anticonvulsants and neuroprotectant, several methylenedioxy-benzodiazepinones have been described as promise neuroactive lead-compounds. Among them, compound 57 (Figure 18) highlighted with $\mathrm{IC}_{50}=2.7 \mu \mathrm{M}$ and good anticonvulsant activity measured in vivo using a mouse maximum electroshock- induced seizure (MES) assay. The central role of benzodioxole scaffold or methylenedioxyphenyl subunit in the activity of compound $\mathbf{5 7}$ was established by the attempt to replace this moiety by a dimethoxyphenyl subunit, resulting in compound 58, with great decrease in AMPA receptor antagonist activity (Figure 12 ). ${ }^{63}$

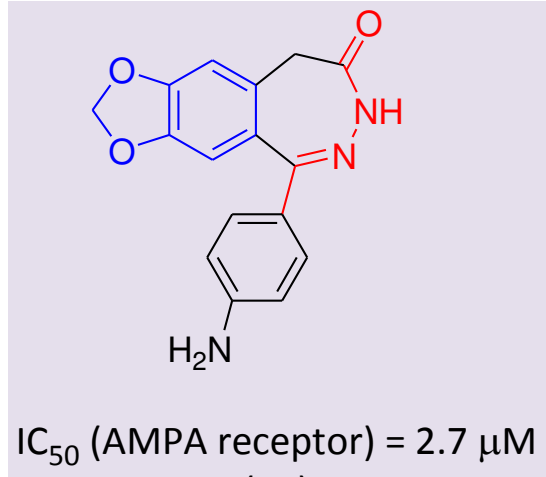

(57)<smiles>COc1cc2c(cc1OC)C(c1ccc(N)cc1)=NNC(=O)C2</smiles>

$I_{50}$ (AMPA receptor) $=128 \mu \mathrm{M}$

(58)

Figure 18. Methylenedioxy-benzodiazepinone (57) and its dimethoxyphenyl analog (58) and their comparative $\mathrm{IC}_{50}$ value against AMPA receptors

Widely distributed in the body, receptors for endothelin (ET) are present in blood vessels, brain, choroid plexus and peripheral nerves. Several endothelin receptor antagonists have been identified, which differ in their selectivity toward the $\mathrm{ET}_{\mathrm{A}}$ and $\mathrm{ET}_{\mathrm{B}}$ receptors. Sitaxentan (59, Figure 19), a sulfonamide class of selective $\mathrm{ET}_{\mathrm{A}}$ receptor antagonist, was approved for the treatment of pulmonary hypertension. This derivative, presenting the 1,3-benzodioxole scaffold, was voluntarily withdraw (by Pfizer in 2010) from all markets worldwide and all ongoing clinical trials were discontinued, based on fatal cases associated with hepatic injury promoted by the use of sitaxentan (59, Figure 19). This compound (59) was also described to be an inhibitor of CYP2C9, with drug-drug interaction with warfarin, and to be a weak inhibitor of CYP2C19 and CYP3A4 . ${ }^{64,65}$

Since the activation of endothelin $\mathrm{ET}_{\mathrm{A}}$ receptors has been implicated in diabetesinduced reductions in peripheral neurovascularization and concomitant endoneurial hypoxia, the amidebenzodioxole derivative ABT-627 (60, Figure 19) was evaluated in the streptozotocininduced diabetic rat model of neuropathic pain. This selective $\mathrm{ET}_{\mathrm{A}}$ antagonist receptor showed significant antinociceptive effect, that was maintained following chronic administration of ABT-627 (60). The inactivity observed for the homologous analogue A192621 (61, Figure 19), a selective $\mathrm{ET}_{\mathrm{B}}$ antagonist receptor, revealed the dependence of selective blockade of $\mathrm{ET}_{\mathrm{A}}$ receptors to attenuate the tactile allodynia in the streptozotocin-treated rat. ${ }^{66,67}$ 


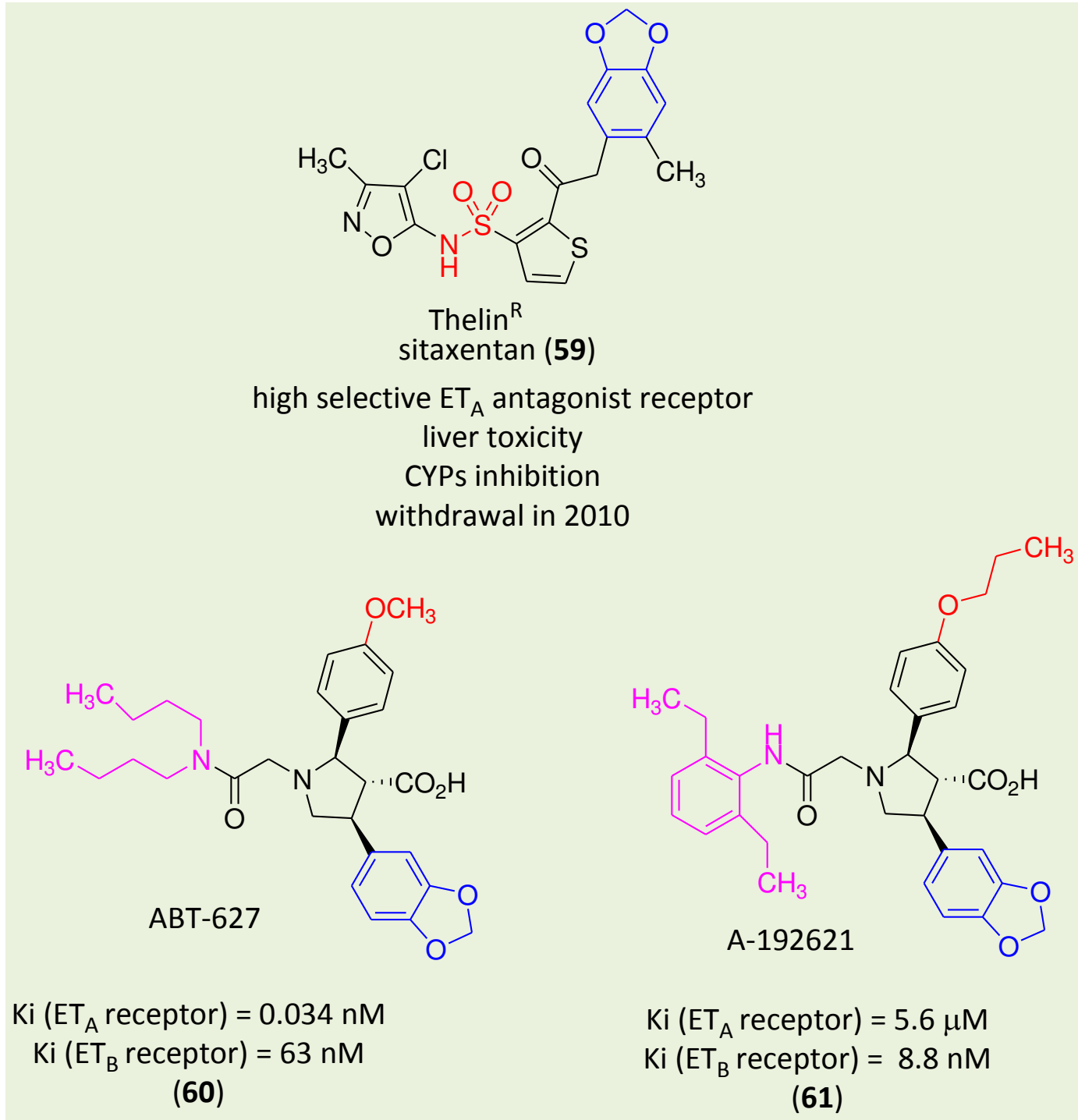

Figure 19. Benzodioxole derivatives (59-61) as endothelin receptor antagonists

Stiripentol (62, Figure 20) is a novel antiepileptic drug produced by Biocodex (Gentilly, France). It has been used as cotherapy for treatment of epilepsy for many years and it has been granted orphan drug status in the European Union for the treatment of severe myoclonic epilepsy in infancy. This benzodioxole-allylic alcohol (62) increases GABAergic transmission, in experimental models, and inhibits CYP3A4, CYP1A2 and CYP2C19 in epileptic patients. ${ }^{68}$ A cyclic stiripentol analogue (63, Figure 20) was developed and displayed a promising anticonvulsant profile with potency comparable with the standard drug $\mathbf{6 2}$ (Figure 20) in subcutaneous pentylenetetrazole induced seizures assay, without any neurotoxicity. ${ }^{69}$ 
<smiles>CC(C)(C)C(O)/C=C/c1ccc2c(c1)OCO2</smiles>

Diacomit $^{R}$ stiripentol (62) $\mathrm{ED}_{50}=115 \mathrm{mg} / \mathrm{kg}$<smiles>CC(C)(C)C1=NN(C(=O)c2ccc(Br)cc2)C(c2ccc3c(c2)OCO3)C1</smiles>

Figure 20. Benzodioxole derivatives (62-63) as anticonvulsant agents

Sigma receptors represent a distinct class of proteins that play an important role in regulating and integrating nervous, endocrine, and immune responses. The two subtypes $(\sigma 1$ and $\sigma 2)$ are expressed in the central nervous system, endocrine and immune systems and in peripheral tissues. They regulate the activity of various ion channels and possess protein chaperone function. The development of $\sigma 1$ receptor ligands could have wide therapeutic application, while the discovery of specific radiotracers for in vivo imaging of $\sigma 1$ receptors may provide the necessary diagnostic tools in combating human diseases related to sigma receptors. In this context, $\mathrm{Li}$ and coworkers $(2011)^{70}$ reported the synthesis of benzodioxole-piperazine derivatives, which showed high subtype selectivity and nanomolar affinity for $\sigma 1$ receptors, like 64 ( $\mathrm{Ki}=0.78 \mathrm{nM}$ ) (Figure 15). From compound 64 , the $\left[{ }^{125} I\right]$-radioactive derivative 65 (Figure 21) was prepared and its in vivo biodistribution was performed in order to determine de radioactivity in organs known to contain $\sigma$-receptors. ${ }^{70}$<smiles>CC(C)C</smiles>

(64)

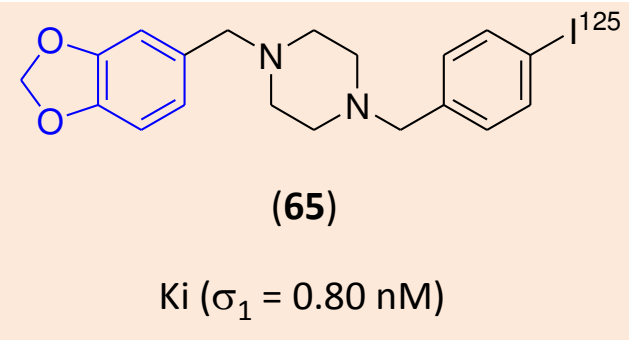

Figure 21. Sigma ( $\sigma 1)$-receptor ligands 64 and the radioactive analogue 65

In attempt to modify the natural $Z$ stilbene benzodioxole derivative, combretastatin A-2 (49), Pettit and coworkers $(2003)^{71}$ proposed modifications on its structure. Among these modifications the replacement of hydroxyl group by an isosteric amine unit provided compound 66, which was able to inhibit tubulin polymerization by binding at the colchicine site and showed potent antiproliferative activity against different human tumor cell lines, such as MCF-7, NCl-H460 and DU145 (Figure 22). ${ }^{71}$ 
<smiles>COc1ccc(/C=C\c2cc(OC)c3c(c2)OCO3)cc1O</smiles>

combretastatin A-2 (49)<smiles>COc1ccc(/C=C\c2cc(OC)c3c(c2)OCO3)cc1N</smiles>

(66)

$$
\begin{array}{ll}
\mathrm{GI}_{50}(\mathrm{MCF}-7)=0.0042 \mu \mathrm{g} / \mathrm{mL} & \mathrm{GI}_{50}(\mathrm{MCF}-7)=0.0047 \mu \mathrm{g} / \mathrm{mL} \\
\mathrm{GI}_{50}(\mathrm{NCl}-\mathrm{H} 460)=0.043 \mu \mathrm{g} / \mathrm{mL} & \mathrm{GI}_{50}(\mathrm{NCl}-\mathrm{H} 460)=0.005 \mu \mathrm{g} / \mathrm{mL} \\
\mathrm{GI}_{50}(\mathrm{DU} 145)=0.0054 \mu \mathrm{g} / \mathrm{mL} & \mathrm{GI}_{50}(\mathrm{DU} 145)=0.028 \mu \mathrm{g} / \mathrm{mL} \\
\mathrm{IC}_{50}(\beta \text {-tubulin })=4.0 \mu \mathrm{M} & \mathrm{IC}_{50}(\beta \text {-tubulin })=3.1 \mu \mathrm{M}
\end{array}
$$

Figure 22. Antiproliferative benzodioxole derivative (66) designed my molecular modification on the natural prototype combretastatin A-2 (49)

Taking into account the role of epidermal growth factor receptor (EGFR) and its four members: HER-1/ErbB-1, ErbB-2 (HER-2/neu), ErbB-3 (HER-3) and ErbB-4 (HER-4), in regulating tumor cell proliferation, differentiation, survival and apoptosis, compounds that inhibit the kinase activity of EGFR and/or HER-2 after binding to its ATP binding site are of potential interest as new antitumor agents. Wang and coworkers $(2013)^{72}$ reported the identification of compound 67 (Figure 23) with potent HER-2 inhibitory activity $\left(\mathrm{IC}_{50}=0.18 \mu \mathrm{M}\right)$. This compound also showed potent antiproliferative activity against human breast cancer cell line MCF-7.

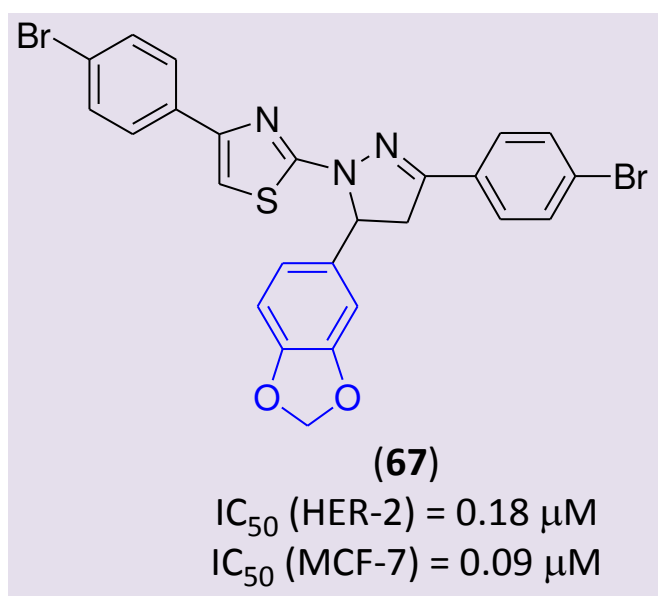

Figure 23. Structure of HER-2 inhibitor 67 and its antiproliferative activity against MCF-7 tumor cell line

Nitidine (68) is a natural benzo[c]phenanthridine alkaloid with good antitumor potency and active as topoisomerase-1 inhibitor (Top-1). Several synthetic nitidine's analogues have been described. Among them, Genz-644282 (69) emerged as a promising Top-1 inhibitor, active in human HT-29 colon carcinoma xenograft model, with satisfactory pharmacokinetic profile (Figure 24). Based on its preclinical activity and safety, Genz644282 (69) was selected for development and is currently undergoing a phase 1 clinical trial. $^{73}$ 
<smiles></smiles>

Figure 24. Natural and synthetic benzodioxole derivatives (68 and $\mathbf{6 9}$, respectively) as topoisomerase-1 inhibitors with great antitumor activity

In order to obtain new antitumor lead candidates, Chen and coworkers $(2013)^{74}$ reported the identification of benzodioxole derivative 72, designed by molecular hybridization between the cytotoxic prototypes 4-aza-podophyllotoxin (70) and combretastatin A4 (71) (Figure 25). This methylenedioxyphenyl-quinolinone

derivative (72) showed great cytotoxic activity against MCF-7 (breast adenocarcinoma) and SKOV-3 (ovarian carcinoma) cancer cell lines. The attempt to replace trimethoxyphenyl subunit by a phenyl ring (73, Figure 25) resulted in loss of cytotoxic activity. ${ }^{74}$

c-Src is a nonreceptor tyrosine kinase involved in the cross-talk and mediation of many signaling pathways that promote cell proliferation, adhesion, invasion, migration, and tumorigenesis. Increased Src activity has been reported in many types of human cancer and there is evidence that c-Src kinase activity is an important component of the invasive phenotype in both early and advanced solid tumors. For these reasons, the discovery of new c-Src inhibitors seems to be an important strategy for the development of new anticancer therapy. ${ }^{75}$ In this context, the benzodioxole anilinoquinazoline derivative AZD0530 (saracatinib, 74, Figure 26) was identified as an orally available Src inhibitor, with potent antimigratory and anti-invasive effects in vitro, able to inhibit metastasis in a murine model of bladder cancer, which is in clinical development for the treatment of a varied types of solid tumors. ${ }^{76,77}$ 
Lima, L. M.

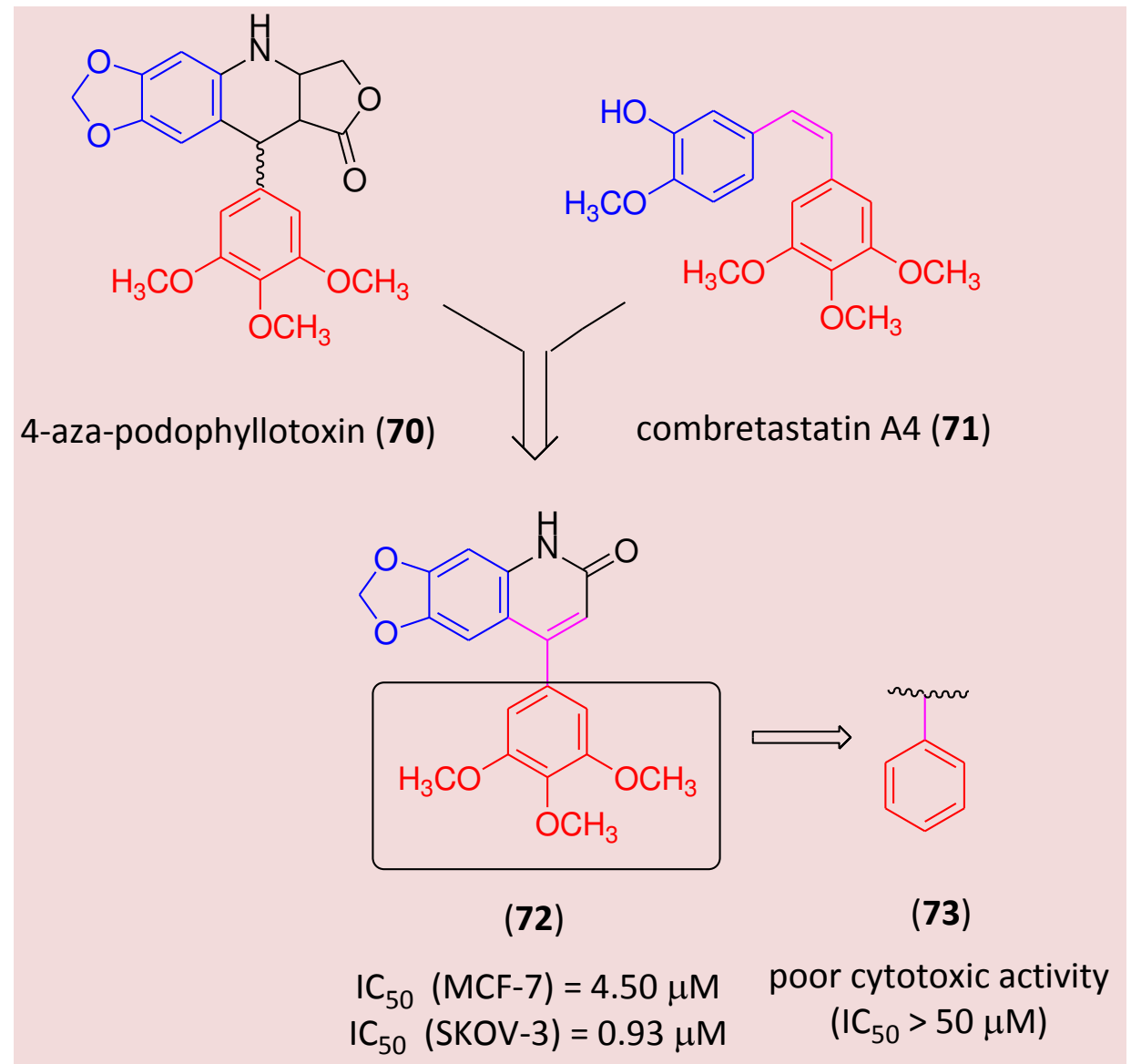

Figure 25. Synthetic benzodioxole derivatives ( $\mathbf{7 2}$ and $\mathbf{7 3}$ ) designed as hybrid between the 4aza-podophyllotoxin (70) and combretastatin A4 (71)

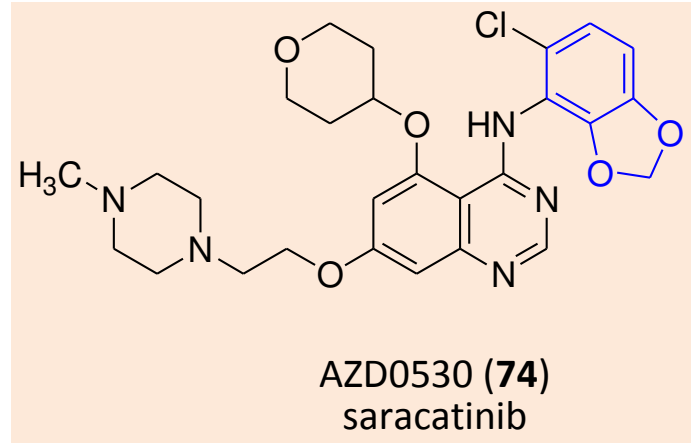

Figure 26. Structure of saracatinib (AZD0530, 74) a new antitumor drug candidate inhibitor of c-Src

Other interesting target to anticancer drug development seems to be heat shock protein 90 (Hsp90). This protein regulates diverse cellular functions and exerts marked effects on normal biology, disease and evolutionary processes. $^{78}$ An important aspect of $\mathrm{Hsp90}$ as a cancer target is the differential effect of $\mathrm{Hsp90}$ inhibitors on cancer cells. Therefore, a variety of inhibitors that target the N-terminal ATP-binding site of Hsp90, blocking essential ATPase activity, have been described. Among them, the benzodioxole derivative MPC-3100 (75, Figure 27) was described as a promising drug candidate, which has completed a phase I clinical evaluation in refractory, or recurrent, 
cancer patients. This purine-based Hsp90 inhibitor showed great cytotoxic activity, adequate pharmacokinetic profile and antitumor effect in a human cancer xenograft model with concomitant and robust Hsp70 mRNA induction, a pharmacodynamic marker of Hsp90 inhibition. ${ }^{79}$

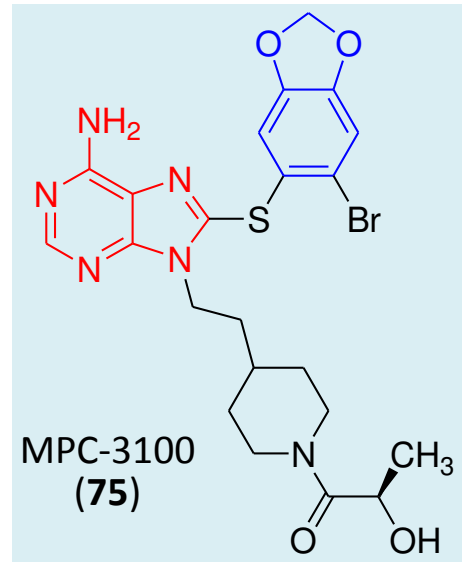

Figure 27. Structure of MPC-3100 (75) a new anticancer drug candidate inhibitor of Hsp90 activity

Lycorine (76) is a natural alkaloid isolated from various Amaryllidaceae species. Modifications on its structure were proposed in order to identify new antimalarial agents, active against chloroquine-sensitive strains of Plasmodium falciparum. In general the lycoryne analogues were less activity than the natural compound (76), standing out the benzodioxole ester (77), which showed similar antiplasmodial activity than $\mathbf{7 6}$ (Figure 28). ${ }^{80}$

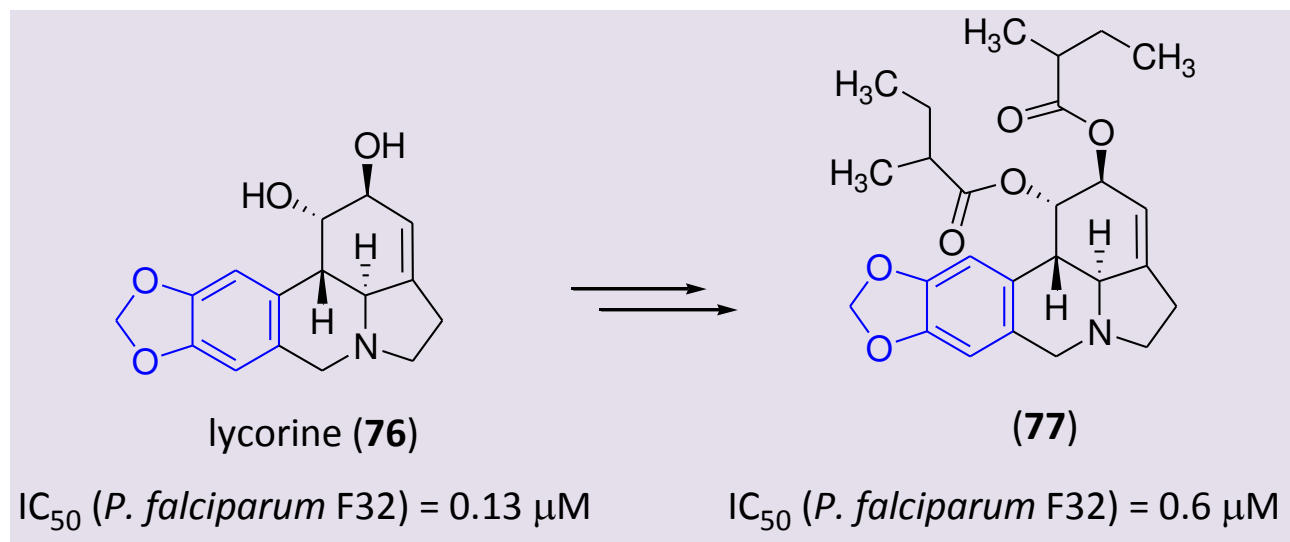

Figure 28. Natural and synthetic benzodioxole derivatives (76 and $\mathbf{7 7}$, respectively) with antiplasmodium activity

Recently, He and coworkers (2014) $)^{81}$ reported a noble activity for a simple and toxic benzodioxole derivative, the methylenedioxy- $\beta$-nitrostyrene (78, Figure 29). This compound (78) inhibits NLRP3 inflammasome, a critical component of the innate immune system, which activation is induced by diverse stimuli associated with bacterial infection or tissue damage. Since, the inappropriate activation of NLRP3 
inflammasome is involved in the pathogenesis of inherited and acquired inflammatory diseases, its inhibition is considered a promise target to develop new anti-inflammatory drugs. ${ }^{82}$ The ability of compound $\mathbf{7 8}$ to inhibit NLRP3 is dependent of the nitrovinyl moiety and seems to be a consequence of covalent reaction between the thiol group of cysteines in target proteins and electrophilic carbon of nitrovinyl subunit. $^{81}$

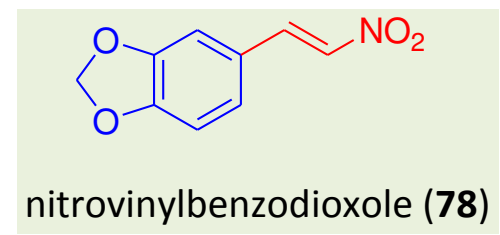

Figure 29. Structure of nitrovinylbenzodioxole (78) an inhibitor of NLRP3 inflammasome

Other important target for de development of anti-inflammatory drug candidates is human leukocyte elastase (HLE). This enzyme is a serine protease found in polymorphonuclear leukocytes, implicated in the extracellular degradation of structural proteins such as elastin and collagen. Therefore, the HLE inhibition has been thought to be strategic to treat diseases such as emphysema and cystic fibrosis. L-694,458 (79, Figure 30) is a potent monocyclic betalactam inhibitor of HLE, presenting satisfactory pharmacokinetic profile in male Sprague-Dawley rats and rhesus monkeys. In both monkey and human liver microsomes L694,458 (79) acted as an inhibitor of testosterone 6 - $\beta$-hydroxylation, indicating its ability to inhibit CYP3A4. ${ }^{83}$

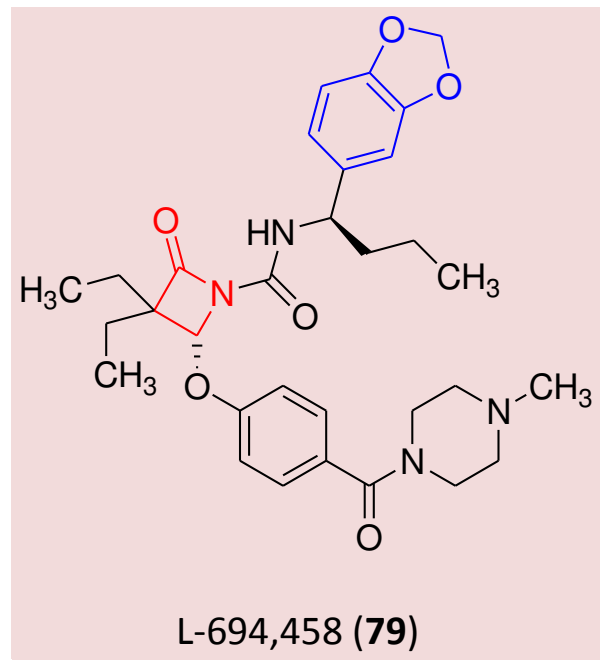

Figure 30. Structure of L-694,458 (79) an inhibitor of human leukocyte elastase

\section{LASSBio's contribution}

During the 1970s, 1980s and 1990s, a major therapeutic interest was attributed to modulation of chemical mediators from the arachidonic acid cascade. By an intricate pathway, arachidonic acid is metabolized in prostaglandins, thromboxane, prostacyclins, leukotrienes, lipoxins and hepoxilin A3, which are known as eicosanoids. This complex family of lipid mediators regulates a wide variety of physiological responses and pathological processes. ${ }^{84}$ 
In the context of the research activities realized at laboratory of evaluation and synthesis of bioactive compounds (LASSBio ${ }^{\circledR}$, in Portuguese: Laboratório de Avaliação e Síntese de Substâncias Bioativas), emphasis was given to the involvement of a particular group of eicosanoids named prostanoids (i.e. prostaglandins, thromboxanes and prostacyclins) in inflammation, platelet aggregation and vascular homeostasis. Therefore, and considering the biophoric features of benzodioxole subunit, the abundance of sassafras oil and the versatility of safrole (1) for chemical modifications, this natural essential oil was thought to be a great starting material to synthesize new antiinflammatory and antithrombotic agents. ${ }^{85}$ Some chronological examples will be discussed as follows.

The first Brazilian work describing the use of safrole (1) in the synthesis of potential anti-inflammatory lead-compound dates from 1982, twelve years before LASSBio's foundation. In a collaboration between professors Eliezer J Barreiro, from Federal University of São Carlos (UFSCar), and Paulo R. R. Costa, from Federal University of Rio de Janeiro (UFRJ), the indolylacetic acids $\mathbf{8 1}$ and 82 were synthetize in 6 and 9 linear steps, respectively, employing safrole (1) as starting material. ${ }^{86}$ These acids were designed considering the ability of indolylacetic acid framework to conjugate the minimal structural requirements to modulate prostaglandins formation, through inhibition of cyclooxygenases, as observed for the prototype indomethacin (80). Therefore, indolylacetic acids 81 and 82 could be hypothetically considered simplified analogues of indomethacin (Figure 31).<smiles>C=CCc1ccc2c(c1)OCO2</smiles>

Figure 31. 3-Indolylacetic acid (81) and its regioisomer $\mathbf{8 2}$ designed as simplified indomethacin (80) analogues and synthesized from safrole (1)

In the context of the same scientific collaboration some prostaglandin and thromboxane analogues were synthesized from safrole..$^{87,88}$ The benzodioxole derivative 84 was designed as structural analogue of prostaglandin $\mathrm{E} 1 \quad\left(\mathrm{PGE}_{1}, \mathbf{8 3}\right)$, an important vasodilatory lipid mediator, preserving in this structure the pharmacophoric points for molecular target recognition (Figure 32). ${ }^{87} \mathrm{~A}$ thromboxane $A_{2}\left(T_{X A_{2}}, 85\right)$ analogue (86) was also synthesized in 6 linear steps from safrole
(Figure 33). ${ }^{88}$ A series of homologous of the $\alpha$ and $\omega$ side-chains of TXA 2 was likewise prepared to furnish different analogues of compound $\mathbf{8 6}$, including derivative $\mathbf{8 7}$. 8,89

The conformational restriction approach was likewise employed on the structure of prostaglandin analogue $\mathbf{8 4}$, in order to design compound $\mathbf{8 8}$ that was synthesized in 8 linear steps from safrole (Figure 34). ${ }^{90}$ 
Lima, L. M.

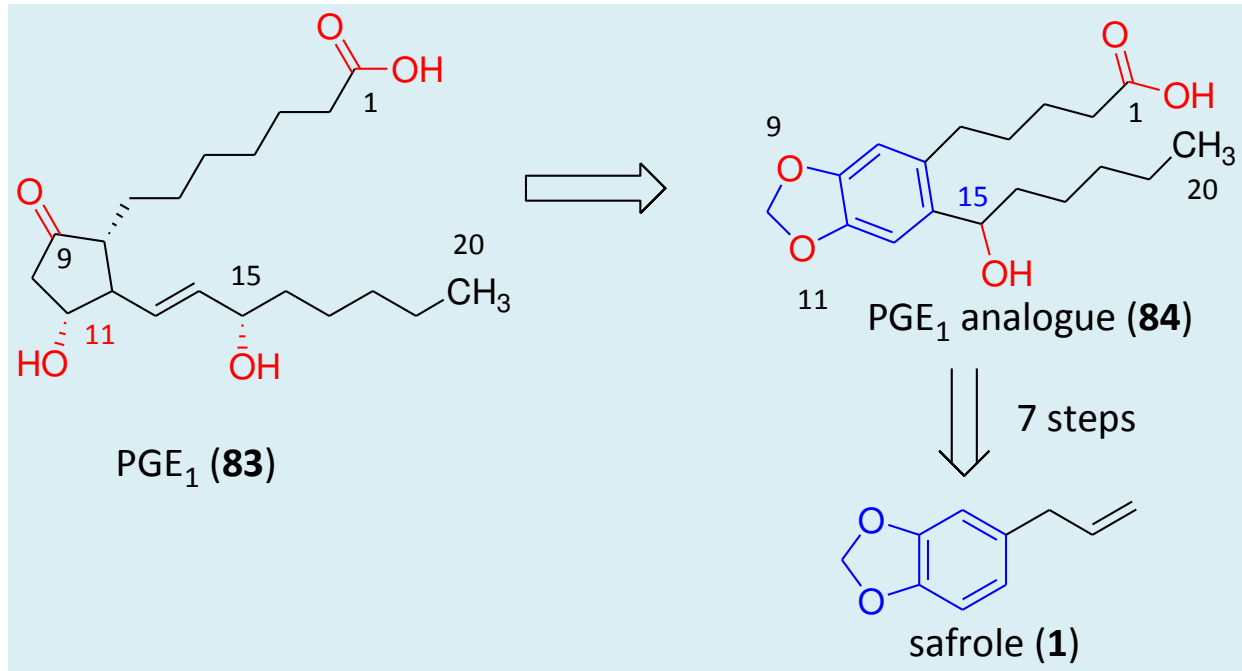

Figure 32. New benzodioxole $\mathrm{PGE}_{1}$ analogue (84) synthesized from safrole (1)

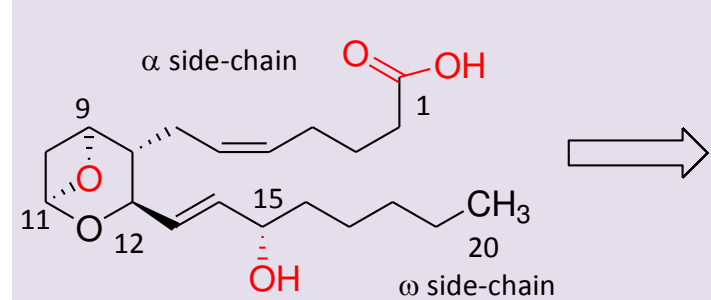

$\mathrm{TXA}_{2}$ (85)

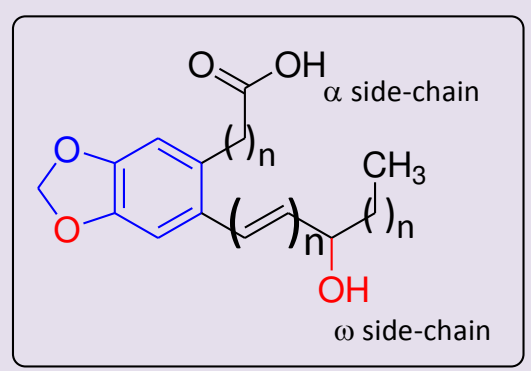

homologous series

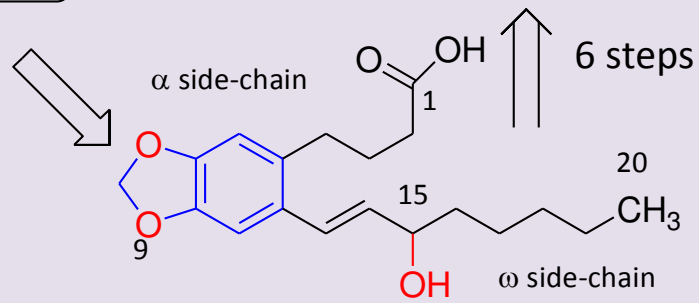

$\mathrm{TXA}_{2}$ analogue (87)

Figure 33. New benzodioxole TXA 2 analogue (86) and its homologous 87 synthesized from safrole (1) 


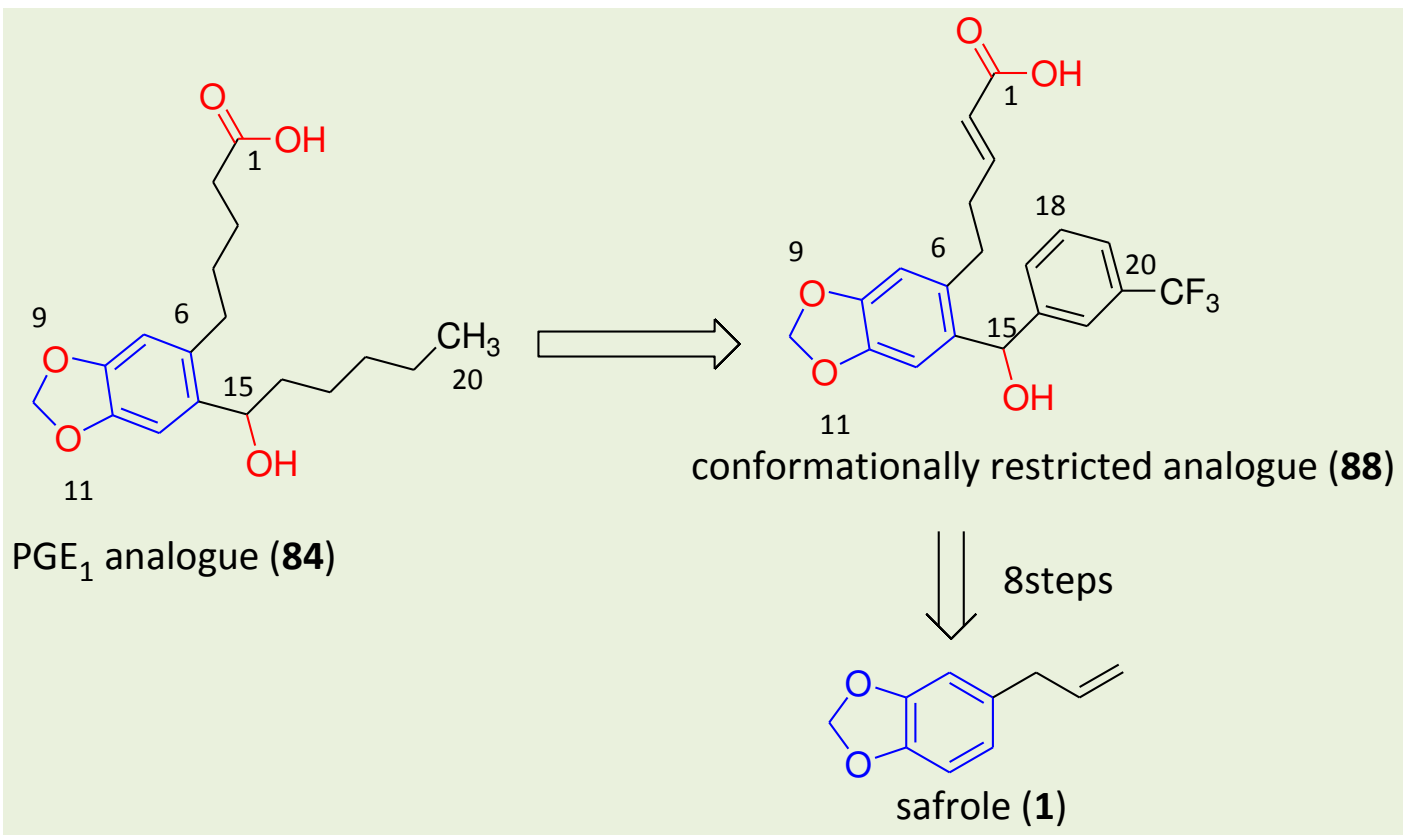

Figure 34. New conformationally restricted analogue (88) of compound 84 synthesized from safrole (1)

The papers published by Pereira and coworkers (1989) ${ }^{91}$ and Barreiro and Lima $(1992)^{92}$ are emblematic landmarks. From the philosophical point of view they can be considered the embryos for LASSBio $^{\circledR}$ (http://www.farmacia.ufrj.br/lassbio/) foundation in 1994. The first successful rapprochement between medicinal chemists and pharmacologists came through these works. From this scientific collaboration with Department of Basic and Clinical Pharmacology of UFRJ, a series of sulindac analogues synthesized from safrole (1) was evaluated in murine model of inflammation by oral administration. This series (91-92, Figure 35) was designed like a me-too drug of sulindac (89), exploring the isosteric relationship between fluorophenyl group and benzodioxole system. The methyl homologous derivatives were also synthesized to furnish asymmetric propanoic acids 93 and 94 (Figure 35). Safrolac derivatives 92 and $\mathbf{9 4}$ were equipotent as analgesic, while compounds 91 and 93 demonstrated de best anti-inflammatory profile, although less potent than the standard sulindac (89). ${ }^{91}$ 

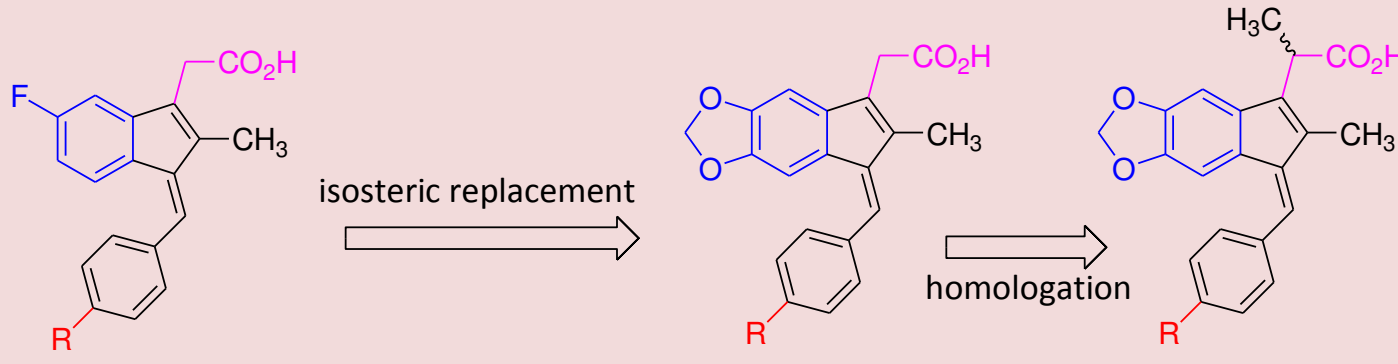

$\mathrm{R}=-\underset{\text { pro-drug }}{-\mathrm{SOCH}_{3} ; \text { sulindac (89) }}$

$$
\begin{aligned}
& \mathrm{R}=-\mathrm{SOCH}_{3} ;(91) \\
& \mathrm{R}=-\mathrm{SCH}_{3} ;(92)
\end{aligned}
$$$$
\mathrm{R}=-\mathrm{SOCH}_{3} ; \text { (93) }
$$$$
\mathrm{R}=-\mathrm{SCH}_{3} ;(94)
$$

$\mathrm{R}=-\mathrm{SCH}_{3} ;$ active metablite $(90)$

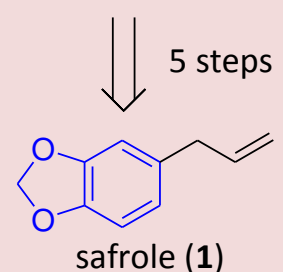

Figure 35. Safrolac derivatives (91-94) designed as me-too analogues of sulindac (89) and synthesized from safrole (1)

In similar manner, others me-too analogues of anti-inflammatory drugs were synthesized from safrole (1) (Figure 36). The safroxican 96 was designed as a retroisoster of piroxicam (95), where the phenyl group was replaced by a benzodioxole subunit and the 2-piridinyl nucleus by a phenyl ring, in a classical isosteric ring interchange. ${ }^{93}$ Safrodolac 98 was also prepared and designed by molecular simplification on structure of etodolac (97), followed by ring isosterism (Figure 36). This analogue (98) showed significant anti-inflammatory activity by oral administration in carrageenan paw edema assay. ${ }^{94}$

In an attempt to optimize the antiinflammatory activity of safrodolac (98), novel spiroisochromanyl acid derivatives (99 and 100) were synthesized in 4 linear steps from safrole (1). These compounds were designed as conformationally restricted analogues of safrodolac (98), by cyclization of pentanoic acid framework into a cyclopentanecarboxylic acid in $\mathbf{9 9}$ or into a cyclohexanecarboxylic acid in the homologous 100 (Figure 37). These restricted analogues showed poor anti-inflammatory profile and a powerful analgesic activity by oral administration. ${ }^{95}$

Assuming that the conformational restriction could be responsible by the loss of anti-inflammatory activity observed for compounds 99 and 100, the benzodioxoleisochromanyl system was modified once more. In this context, safrodolac (98) was modified through functionalization of carboxylic acid into an $\mathrm{N}$-acylhydrazone (Figure 38). Among the isochromanyl- $N$ acylhydrazones synthesized using safrole (1) as starting material, compound $\mathbf{1 0 1}$ standing out. This compound showed remarkable analgesic activity in acetic acid-induced abdominal constriction in mice, although it still presents unsatisfactory antiinflammatory activity in carrageenan-induced paw edema in rats. ${ }^{96}$ 
<smiles>CN1C(C(=O)Nc2ccccn2)=C(O)c2ccccc2S1(=O)=O</smiles>

piroxicam (95)

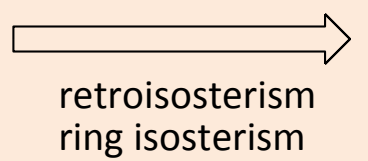

ring isosterism

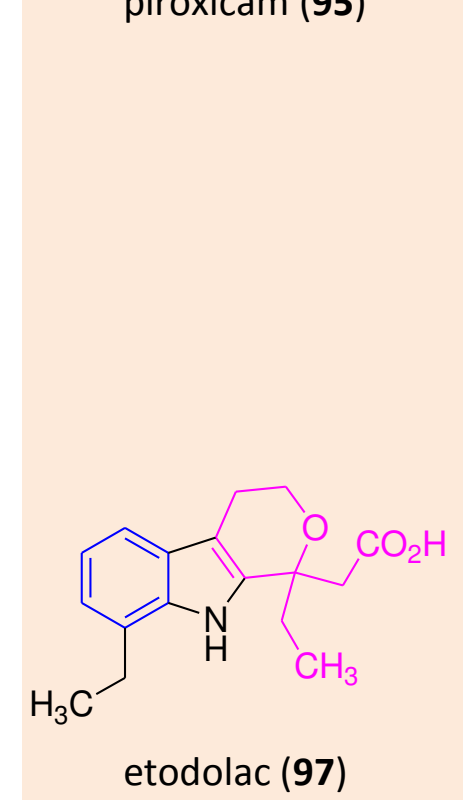

retroisosterism ring isosterism<smiles>CCCCC(=O)O[Mg]</smiles>
safroxican (96)

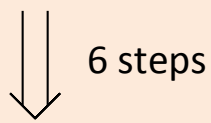<smiles>C=CCc1ccc2c(c1)OCO2</smiles>
safrole (1) 2 steps

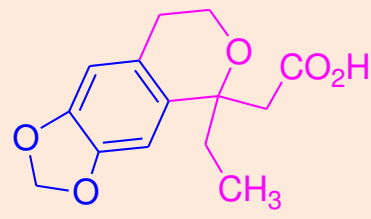

safrodolac (98)

Figure 36. Safroxican (96) and safrodolac (98) designed as me-too analogues of piroxicam (95) and etodolac (97) and synthesized from safrole (1)

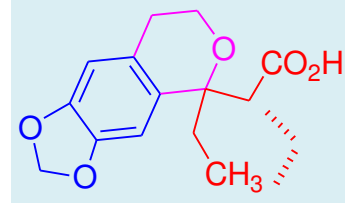

safrodolac (98)

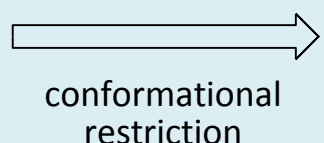

restriction

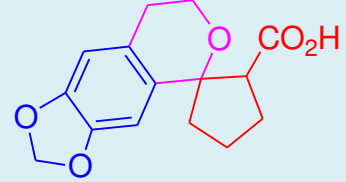

(99)

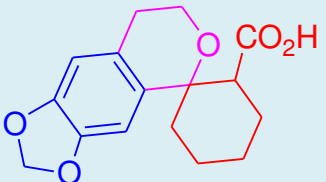

(100)

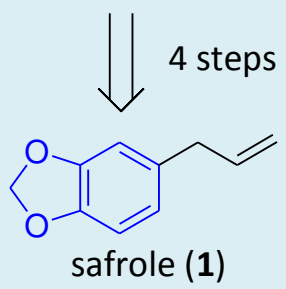

Figure 37. Spiro-safrodolac analogues (99 and 100) synthesized from safrole (1) 


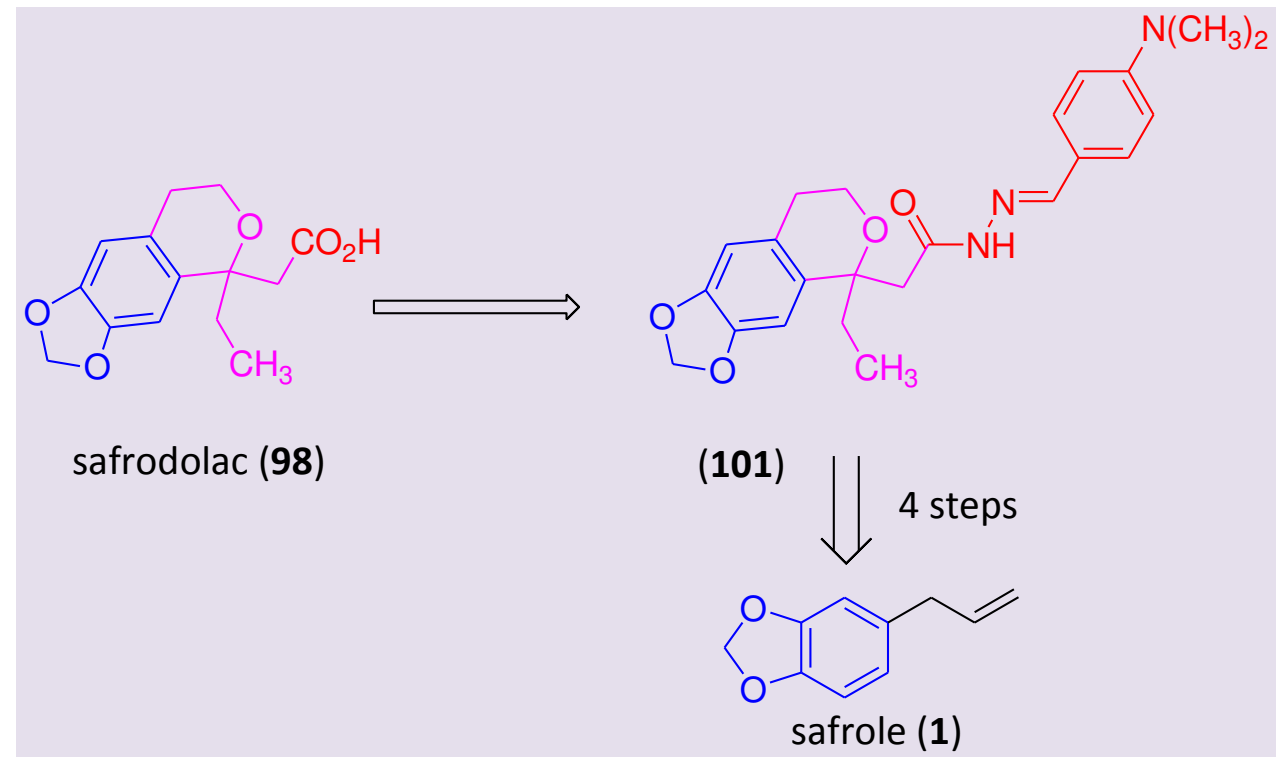

Figure 38. Safrodolac analogue (101) synthesized from safrole (1)

The recognition of the existence of two cyclooxygenase (COX) or prostaglandinendoperoxide synthase (PGHS) isoforms prompted the search for selective COX inhibitors. The assumption that COX-1 was produced constitutively (i.e., gastric mucosa) whereas COX-2 was inducible (i.e., in sites of inflammation), indicated the possibility to modulate the formation of prostanoids related to inflammatory response, without interference with those related to homeostatic functions. Based on this statement, several COX-2 inhibitors were developed and some of them were introduced as second generation of nonsteroidal anti-inflammatory drugs, such as celecoxib and rofecoxib. ${ }^{97}$

Aiming to discover a new COX-2 inhibitor, Lages and co-workers $(1998)^{98}$ described the design of safrolide 103, planned exploring the isosteric relationship between indanone ring of the prototype flosulide (102), a selective COX-2 inhibitor, and benzodioxole system; and the isosteric replacement of oxygen atom by a methylene group in compound 103 (Figure 39). This flosulide analogue (103) was synthesized in 6 linear steps from safrole (1) and showed antiinflammatory activity, by oral administration, in carrageenan-induced rat pleurisy and paw edema models. ${ }^{98}$

Benzodioxole- $N$-acylhydrazone derivatives with outstanding analgesic activity were also synthesized from safrole (1). Compound 104, designed by molecular simplification on the structure of prototype 101, showed similar analgesic activity than indomethacin in acidacetic induced constrictions in mice, while its linear C2 homologous 105, less conformationally restricted, showed superior analgesic activity than the standard indomethacin, by oral administration in screening dose of $100 \mu \mathrm{Mol} / \mathrm{kg}$ (Figure 40). ${ }^{99}$ 


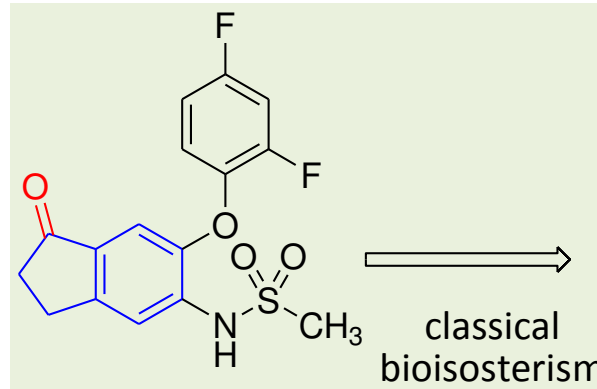<smiles>CS(=O)(=O)Nc1cc2c(cc1Cc1ccccc1)OCO2</smiles>

flosulide (102)

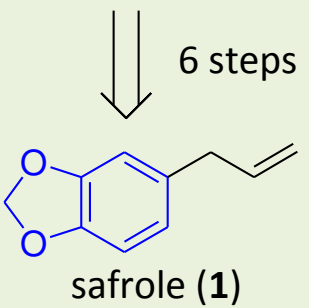

Figure 39. Safrolide analogue (103) synthesized from safrole (1) and designed from COX-2 inhibitor flosulide (102)

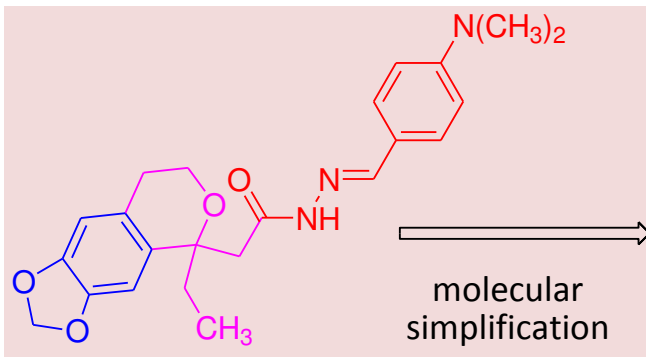

(101)

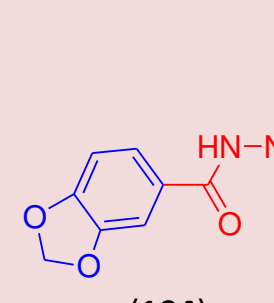

(104)

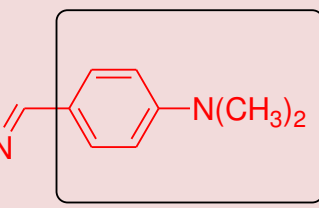

ring isosteric replacement; isosteric substituent replacement

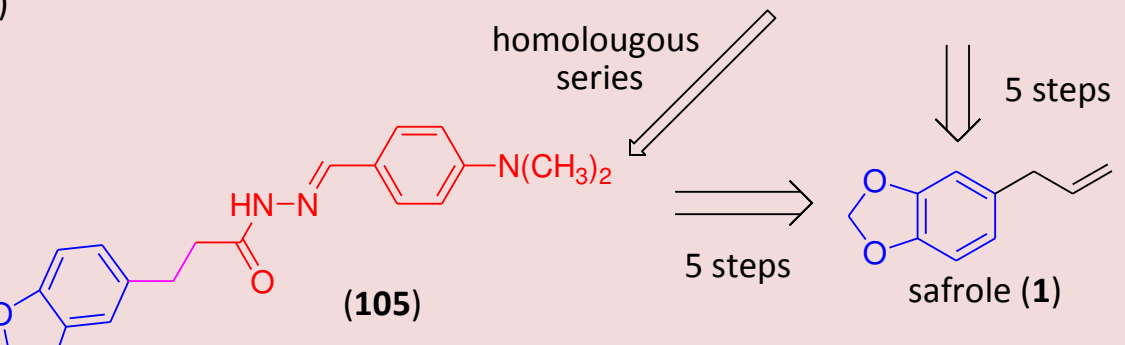

Figure 40. Analgesic benzodioxole derivatives (104 and 105) synthesized from safrole (1) and designed by molecular simplification on prototype 101

Exploring the isosteric relationship between carbonyl and sulfonyl functions, a series of $\mathrm{N}$-sulfonylhydrazones was designed and synthesized from safrole (1). Comparatively to the $\mathrm{N}$-acylhydrazone 104 , compound $\mathbf{1 0 6}$ was demonstrated to be less analgesic. $^{99}$ The further substitution of $\mathrm{N}$ dimethylamine group by acidic one, such as $\mathrm{CO}_{2} \mathrm{H} \mathrm{(107)}$ or $\mathrm{OCH}_{2} \mathrm{CO}_{2} \mathrm{H}$ (108) (Figure 41), resulted in increase of analgesic activity and satisfactory anti-inflammatory profile. ${ }^{100}$ 


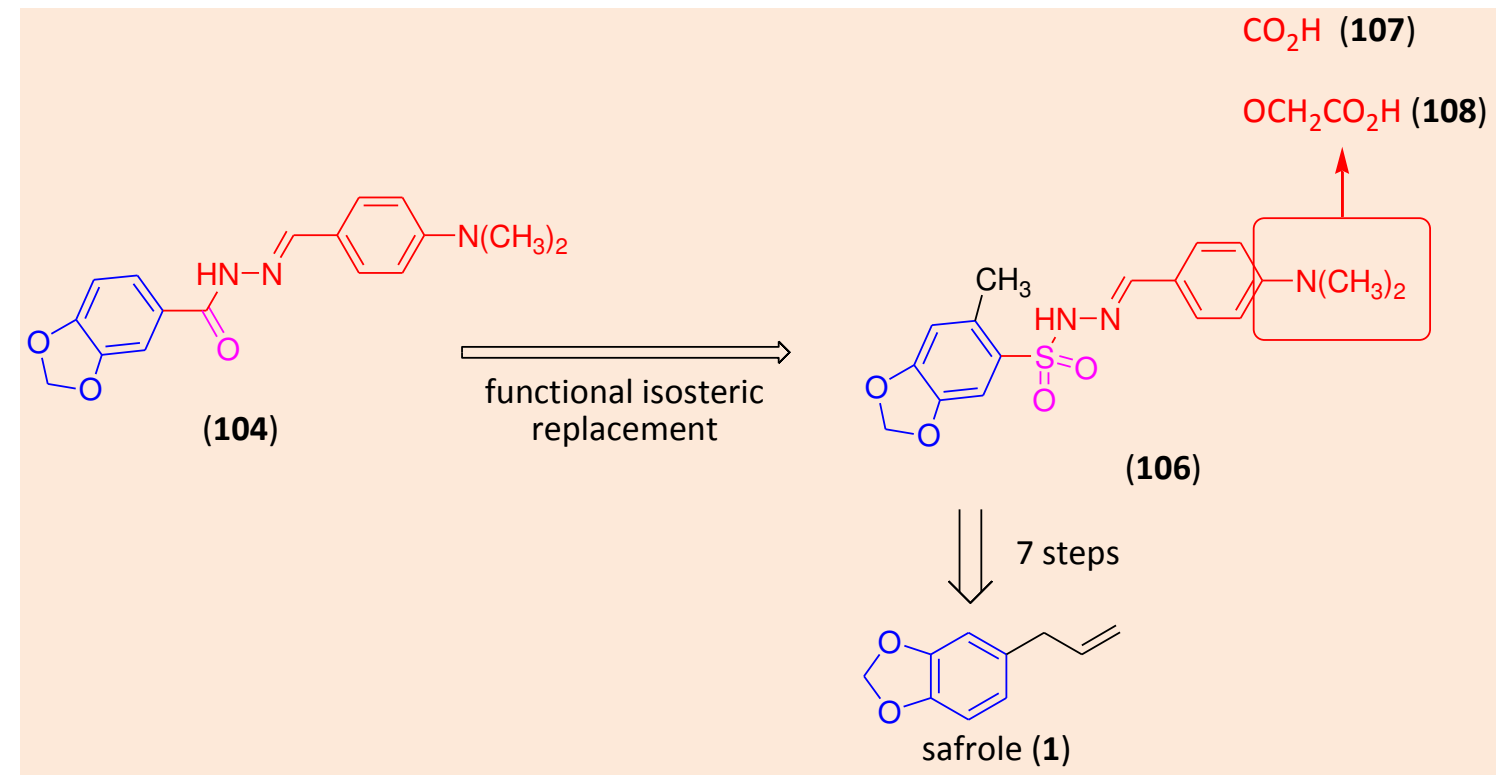

Figure 41. Benzodioxole- $N$-sulfonylhydrazone derivatives (106-108) synthesized from safrole (1) and designed by isosteric replacement on prototype 104

Further modifications were also performed on structure of linear homologous prototype $\mathbf{1 0 5}$. These modifications were based on the isosteric replacement of divalent groups $\left(\mathrm{CH}_{2} \times \mathrm{O}\right)$ and the introduction of a monovalent electron withdrawing group (i.e. $\mathrm{NO}_{2}$ ) at carbon 6 of benzodioxole subunity, resulting in design conception of compounds 109 and $\mathbf{1 1 0}$
(Figure 42). These compounds showed better analgesic activity than dypyrone, in screening dose of $100 \mu \mathrm{Mol} / \mathrm{kg}$ (per os) in acid-acetic induced constrictions in mice model. The loss of analgesic activity found for compound 111, in same experimental conditions, indicated the pharmacophoric profile of orthonitrophenyl framework (Figure 31). ${ }^{101}$

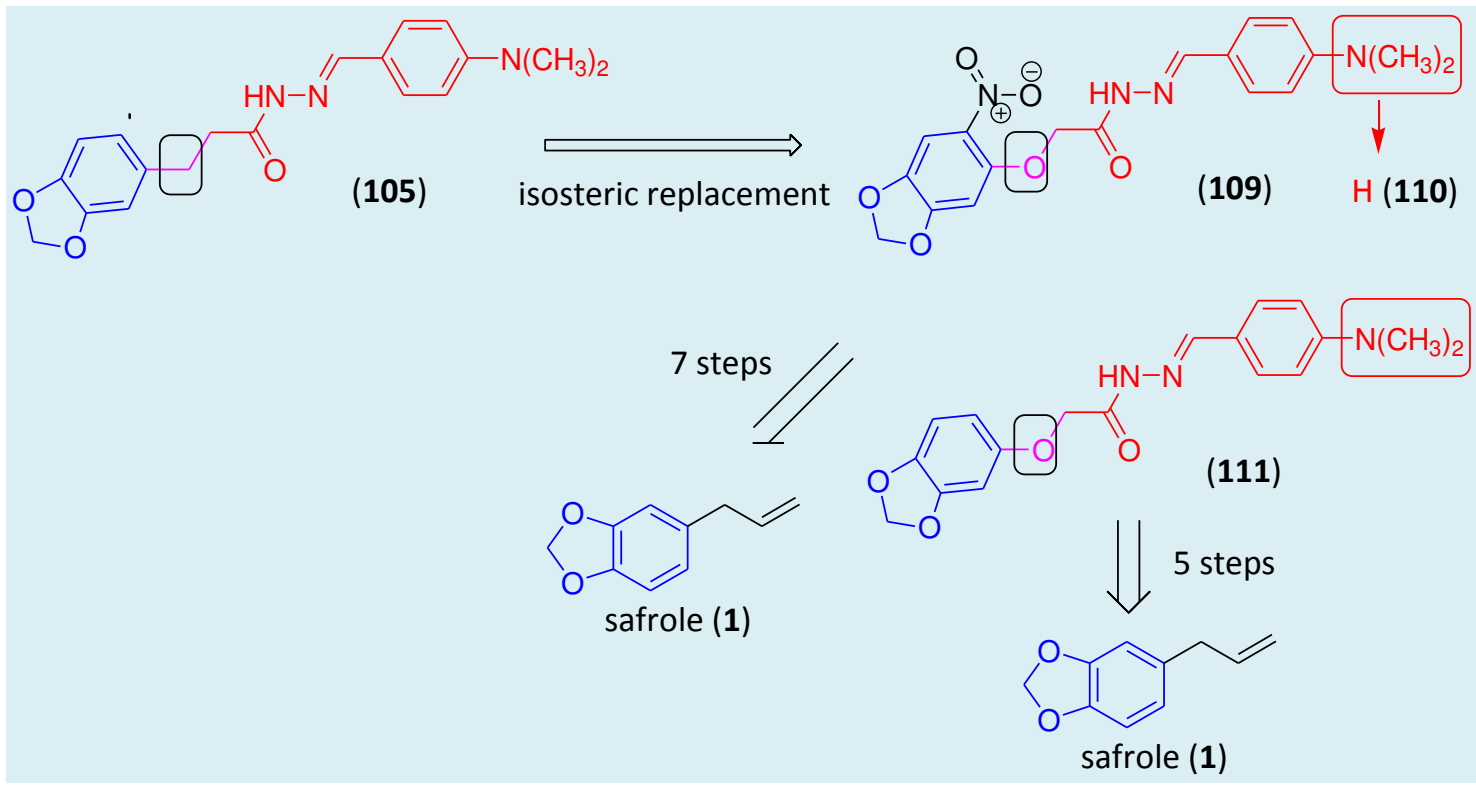

Figure 42. Benzodioxole- $N$-acylhydrazone derivatives (109-111) synthesized from safrole (1) and designed by isosteric replacement on prototype 105 
In order to improve the anti-inflammatory and analgesic profile of prototype $\mathbf{1 1 0}$, a new series of nitro-benzodioxole- $\mathrm{N}$-acylhydrazone derivatives were proposed, by molecular hybridization between $\mathbf{1 1 0}$ and nimesulide (112), a selective COX-2 inhibitor, followed by elimination of oxa-alkyl $\left(\mathrm{OCH}_{2}\right)$ side chain (Figure 43). The idealized hydrid compound (113) led the design of compounds 114 and 115 by replacement of phenylsulfonylamine moiety by a diterbutilphenol and phenyl subunits, respectively (Figure 43). In carrageenan-induced rat paw edema assay, compound $\mathbf{1 1 5}$ was inactive, while $\mathbf{1 1 4}$ showed significant anti-inflammatory activity. Curiously this compound (114) showed great antinociceptive activity in the first phase of formalin test and was inactive in the second phase, showing a pharmacological profile different from non-steroidal antiinflammatory drugs. These results indicated a central analgesic activity that was confirmed by the hot plate test in mice. Further studies were realized and characterized compound 114 as a non-selective cannabinoid ligand having also antioxidant properties. ${ }^{102}$

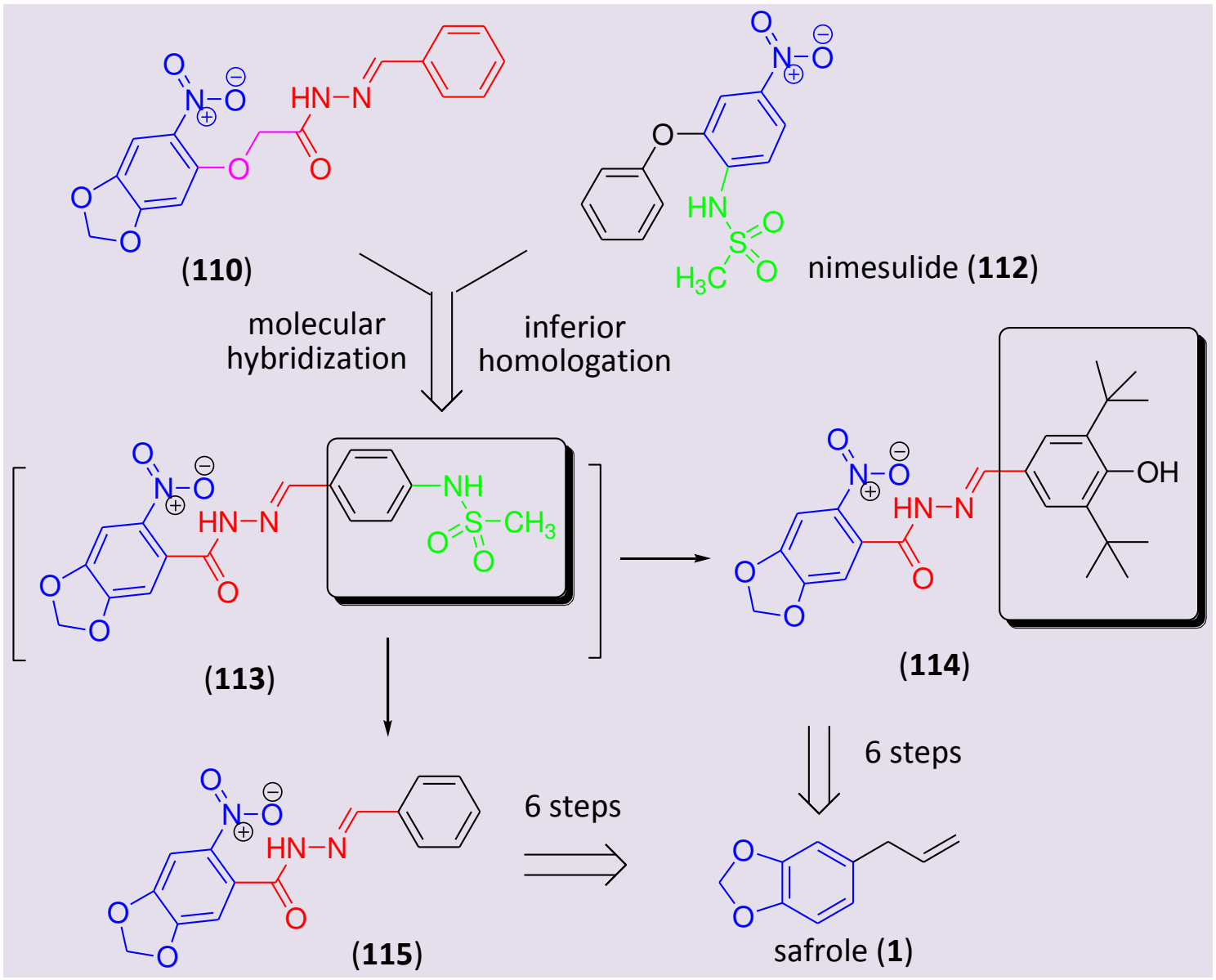

Figure 43. Nitro-benzodioxole- $N$-acylhydrazone derivatives (114 and 115) designed by application of molecular hybridization and inferior homologation on structure of prototypes 110 and 112 and synthesized from safrole

Benzodioxole derivatives with antiplatelet activity, planned as new antithrombotic drug candidates, were synthesized and designed in order to modulate de effects evoked by the prostanoid thromboxane $A_{2}\left(T_{X A_{2}}\right)$. TXA 2 (79) is an unstable arachidonic acid metabolite that plays a key role in normal physiology and control of vascular tone and platelet 
aggregation. It is a vasoconstrictor and potent hypertensive agent, able to trigger platelet aggregation. It achieves its biological effect through interaction with specific receptors named thromboxane $A_{2}$ receptors (TP). Therefore, the design of TP antagonists has been proposed as potential therapeutic agent for thrombosis. ${ }^{103}$

Considering the structure of sulotroban (BM 13.177; 116), a selective TP receptor antagonist, and looking for new antithrombotic agents, a me-too derivative (117) was proposed by replacing the phenyl ring of $\mathbf{1 1 6}$ by the 1-methyl-4,5-benzodioxole subunit (Figure 44). Compound 117, named safroloban, was able to inhibit platelet aggregation induced by a stable $\mathrm{TXA}_{2}$ analogue (U-46619). However the low potency observed for safroloban $\left(\mathrm{IC}_{50}=329\right.$ $\mu \mathrm{M})$ indicated the detrimental role of the 1methyl-4,5-benzodioxole moiety for the antiplatelet activity. ${ }^{104}$ The simultaneous attempt to design a hydrid between safroloban (117) and SQ29,548 (118), a highly selective TP receptor antagonist, also resulted in compound with weak platelet antiaggregant activity (Figure 45). ${ }^{105}$

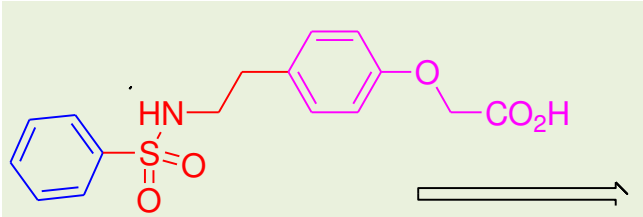

sulotroban (116)

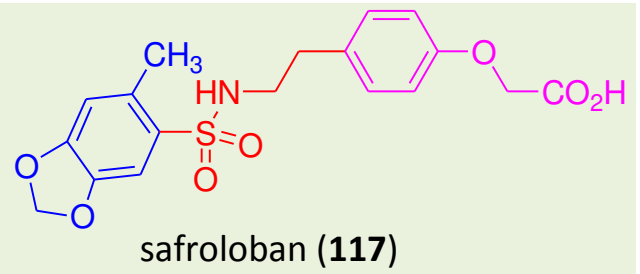

$\Downarrow$ 7steps<smiles>C=CCc1ccc2c(c1)OCO2</smiles>

safrole (1)

Figure 44. Safroloban (111) a me-too analogue of sulotroban (110) synthesized from safrole (1)

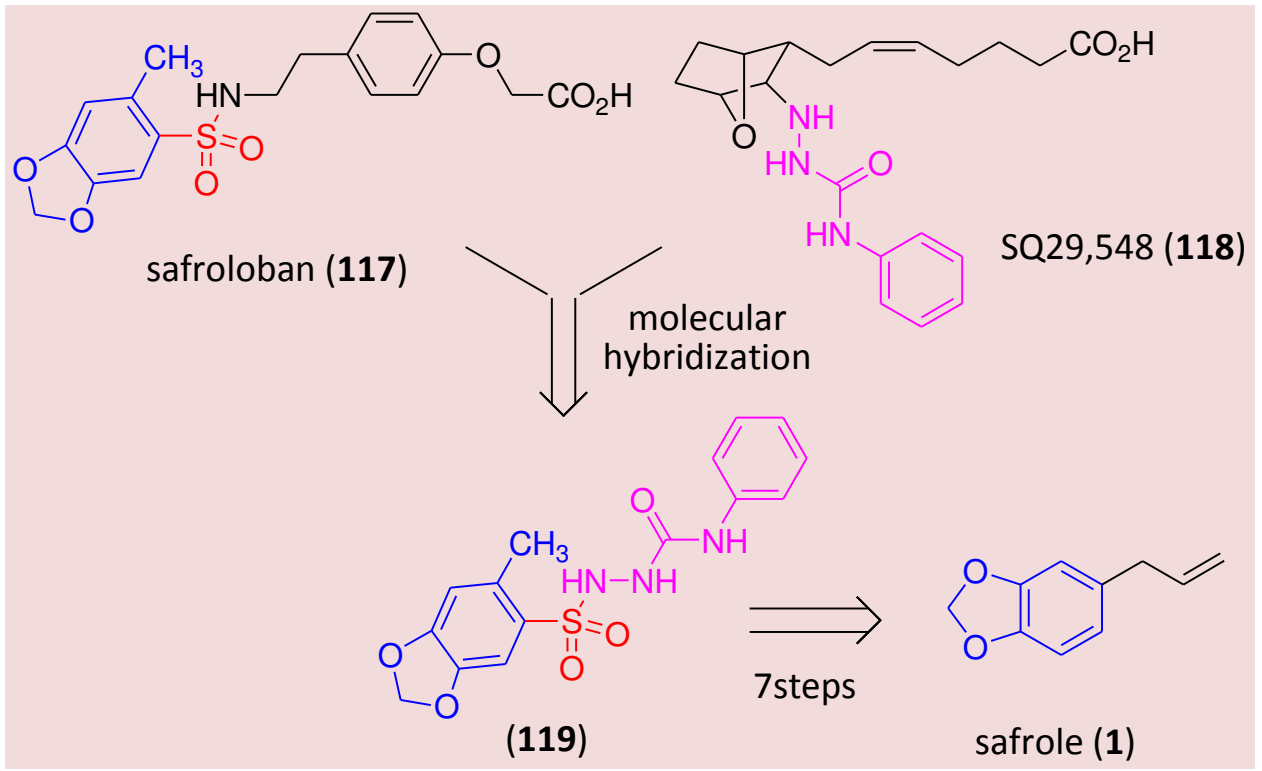

Figure 45. Benzodioxole-sulfonylsemicarbazide (119) designed by molecular hybridization between safroloban (117) and SQ29,548 (118) and synthesized from safrole (1) 
Safrole (1) was also used as starting material for the synthesis of a new structural analogue of ridogrel (120), a dual thromboxane synthase inhibitor and receptor antagonist. This analogue (121) was designed by the replacement of 3-pyridyl ring of $\mathbf{1 2 0}$ by a benzodioxole subunit, followed by cyclization of oxime side-chain, in order to obtain a conformationally restricted analogue (Figure 46). Although safrodogrel (121) retains, in theory, all the pharmacophoric points to interact with the targets (TP receptor and thromboxane synthase), it was unable to inhibit platelet aggregation. This result can indicate that comparatively with ridogrel (120) compound $\mathbf{1 2 1}$ has the pharmacophoric points in inadequate geometry or conformation, preventing their recognition by the receptor sites. ${ }^{106}$

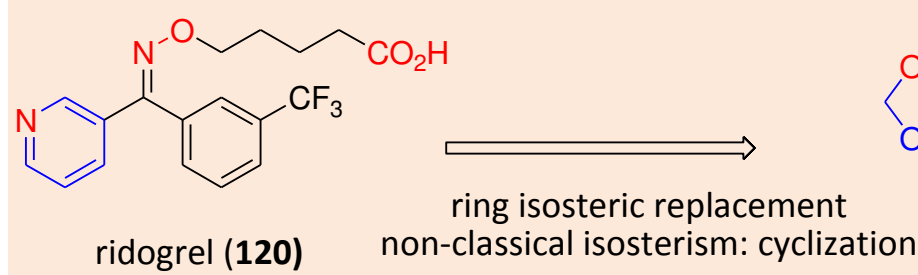

ridogrel (120)<smiles>O=C(O)Cc1ccc(CO/N=C(/c2cccc(C(F)(F)F)c2)c2ccc3c(c2)OCO3)cc1</smiles>

safrodogrel (121)

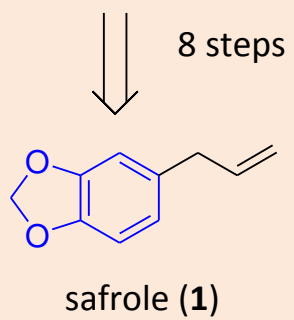

Figure 46. Safrodogrel (121) a me-too analogue of ridogrel (120) synthesized from safrole (1)

In the context of LASSBio's research activities, safrole (1) was still employed in the synthesis of bioactive compounds not related to arachidonic acid cascade, and some examples will be presented.

Thrombin is a serine protease that plays a central role in thrombosis and hemostasis, not only by its ability to convert fibrinogen into fibrin, but also by direct stimulation of platelet aggregation. Therefore, thrombin Inhibitors have long been recognized as potential therapeutic agents for the treatment of a variety of thrombotic disorders. Searching for new anti- thrombin derivative, the arylsulfonate- $N$ acylhydrazone (125) was designed by molecular hybridization between the prototypes 122, 123 and ximegalatran (124) (Figure 47). Curiously, compound having the carboxylic acid (126) instead of $\mathrm{N}$ hydroxyamidine subunit (125) inhibited platelet aggregation induced by thrombin, while compound $\mathbf{1 2 5}$ didn't. This compound (126) also showed antithrombotic effects in a pulmonary thromboembolism model induced by thrombin in mouse, by oral administration. ${ }^{107}$ 


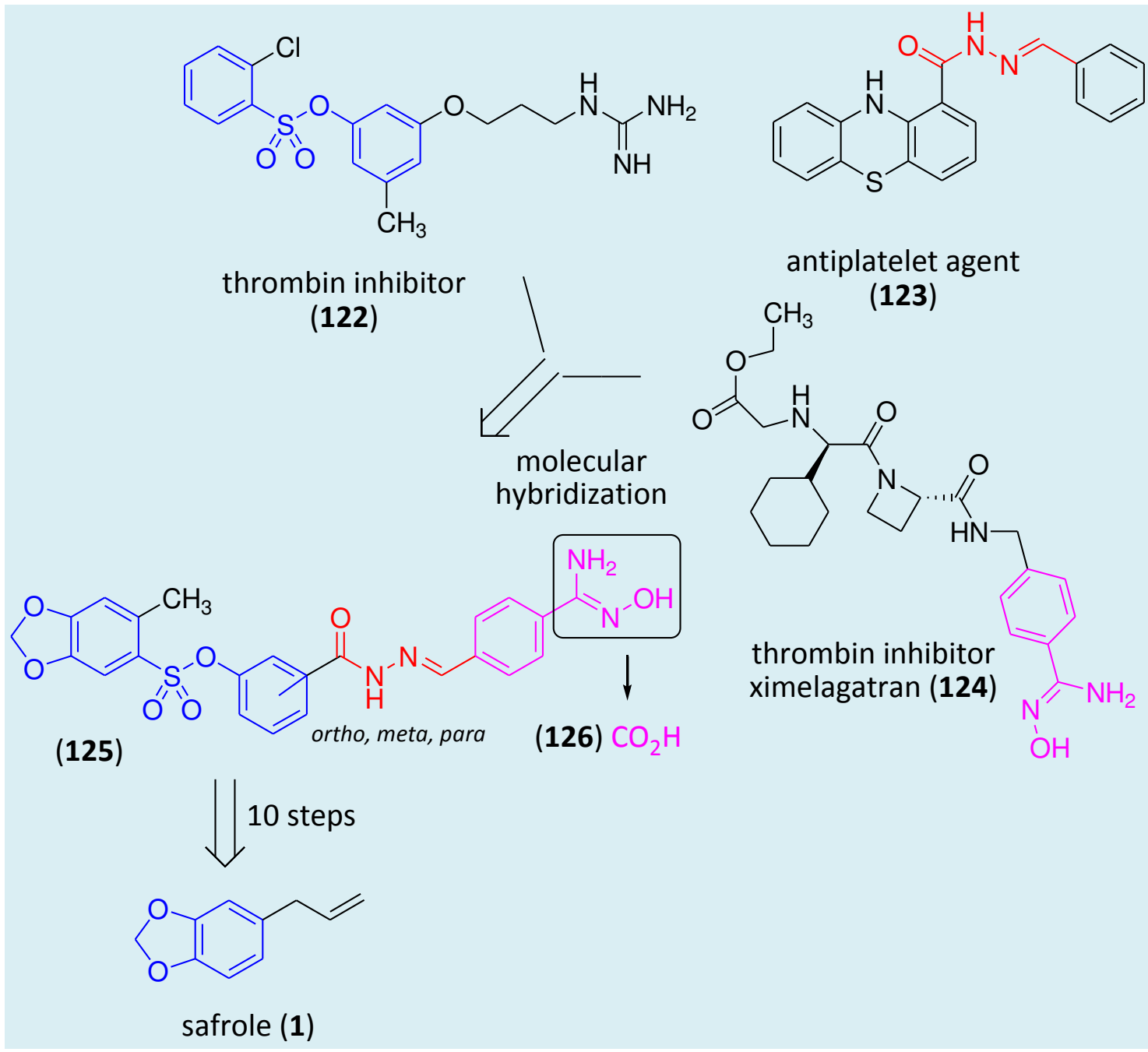

Figure 47. Arylsulfonate- $N$-acylhydrazones (125 and 126) designed by molecular hybridization between prototypes 122, 123 and 124, and synthesized from safrole (1)

p38 Mitogen-activated protein kinase (p38 MAPK) is an important signal transducing enzyme involved in many cellular regulation process, pain and inflammation. p38 MAPK activation occurs in response to several extracellular stimuli such as UV light, heat, osmotic shock, inflammatory cytokines and growth factors. Its inhibition has been proposed as a therapeutic strategy to treat inflammatory disorders and neuropathic pain. Aiming to discover a new p38 MAPK inhibitor, compound $\mathbf{1 2 8}$ was designed by ring isosteric replacement of thiophene by quinoline, maintenance of urea pharmacophoric group and the ester subunit present in the prototype GK-00687 (127) (Figure 48). Further substitution of phenyl ring by a cyclohexyl unit resulted in the most promise derivative from the series (129). This compound (129, Figure 48) showed, by docking studies, favorable interactions with p38 MAPK, binding in the same region proposed for binding of GK-0068. It also presented great analgesic and antiinflammatory activities in antigen (mBSA)induced arthritis and rat paw edema models, and was able to modulate TNF $\alpha$ production and inhibited LPS-induced p38 MAPK phosphorylation in lung tissue and in isolated macrophages. ${ }^{108,109}$ 


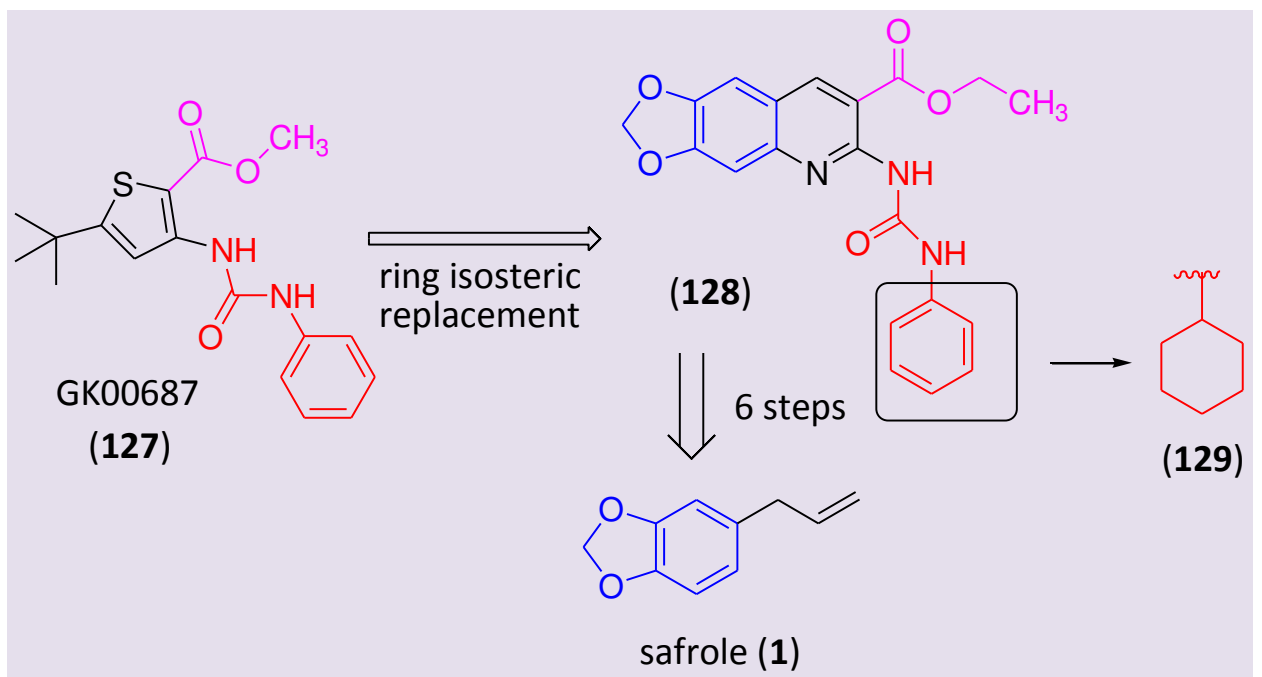

Figure 48. Urea derivatives (122 and 123) designed by ring isosteric replacement on the prototype GK00687 (121) and synthesized from safrole (1)

Peroxisome receptor gamma (PPAR $\gamma$ ) is the subtype gamma of a family of transcription factors that regulate uptake of circulating fatty acids into fat cells and the shifting of lipid stores from extra-adipose to adipose tissue, having an essential role in adipogenesis and lipogenesis. It is the molecular target of antidiabetic drugs, like rosiglitazone (130). Searching for a new PPAR $\gamma$ agonist for the treatment of diabetes mellitus, a virtual screening was realized in order to identify from LASSBio's chemolibrary compounds that can fulfill the minimum structural requirements for PPAR $\gamma$ ligands. From these studies, compound 107 and its regioisomer 131 standing out (Figure 49), having more energetically favorable interactions with the agonist binding site than the standard rosiglitazone, by flexible docking study using program FlexE. In murine model of diabetes the regiosomer $131(20 \mathrm{mg} / \mathrm{kg}$, i.p.) reduced hyperglycemia and diabetic neuropathy. ${ }^{110}$

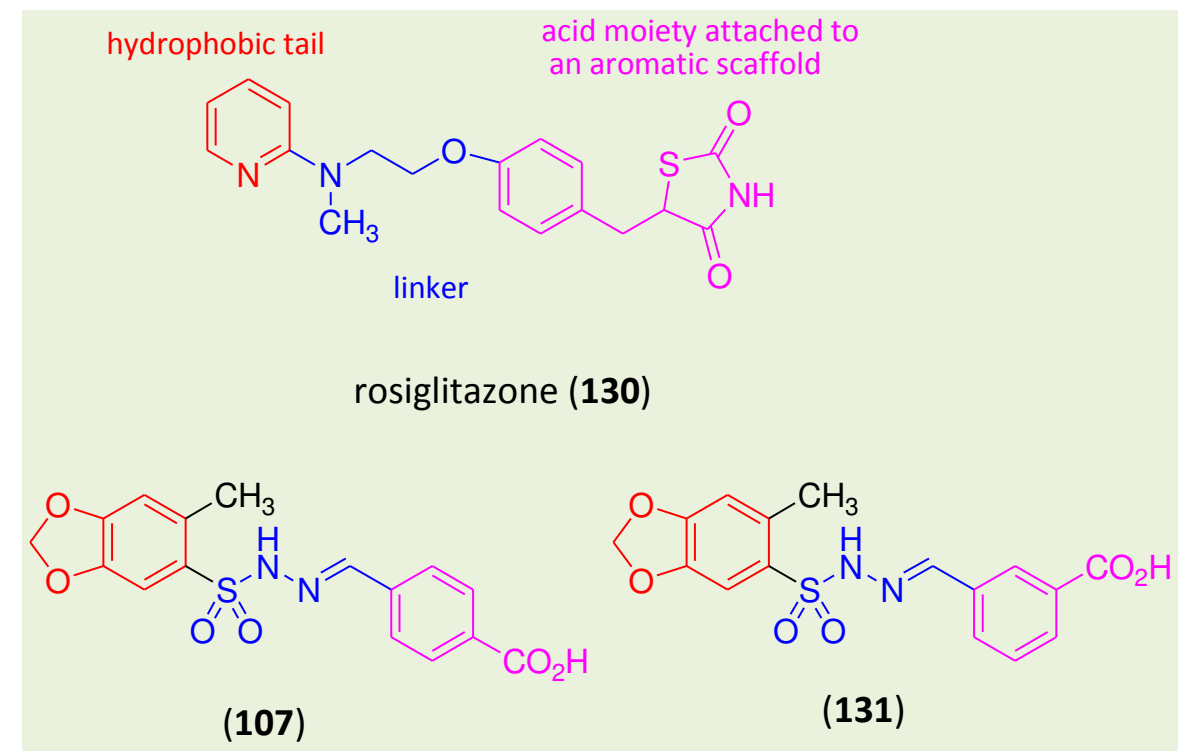

Figure 49. Rosiglitazone (130) and its structural requirements for PPAR $\gamma$ activation and the regioisomers 107 and 131 
Benign prostatic hyperplasia (BPH) is a progressive disease, characterized by a noncancerous enlargement of the prostate gland, resulting in symptoms such as frequent urination, urgency, nocturia, decreased and intermittent force of stream, and the sensation of incomplete bladder emptying. Several $\alpha_{1}$-adrenergic receptors antagonists can be used in the treatment of symptomatic $\mathrm{BPH}$. Among the $\alpha_{1}$-adrenergic receptors, subtype $\alpha_{1 \mathrm{~A}}$ is the predominantly expressed in human prostate. In attempt to discover new drugs candidates to treat $\mathrm{BPH}$ a series of functionalized benzodioxole methylenepiperazine was designed, considering the pharmacophoric models proposed for $\alpha_{1 A}$ antagonist. From this studies compound 133 (Figure 50) highlighted as a novel potent and selective $\alpha_{1 \mathrm{~A} / 1 \mathrm{D}}(\mathrm{Ki}=0.14 \mathrm{nM}$ and $0.025 \mathrm{nM}$, respectively) antagonist, 120 -fold more potent than BMY-7378 as $\alpha_{1 \mathrm{D}}$ antagonist. ${ }^{111}$<smiles>COc1ccccc1CN1CCN(CCN2C(=O)CC3(CCCC3)CC2=O)CC1</smiles>

BMY7378 (132)<smiles>COc1ccccc1CN1CCN(CCc2ccc3c(c2)OCO3)CC1</smiles>

(133)

Figure 50. BM\&7378 (132) and the benzodioxole derivative (133), a potent $\alpha_{1 \mathrm{~A} / 1 \mathrm{D}}$ receptor antagonist

An emblematic example of benzodioxole derivative synthesized in LASSBio $^{\circledR}$, having an exceptional myriad of pharmacological activity, is compound 134, named LASSBio294 (Figure 51). This benzodioxole- $N$ acylhydrazone derivative has inotropic and lusitropic activities; being able to decrease cardiac remodeling and to improve $\mathrm{Ca}^{2+}$ Influx into sarcoplasmic reticulum after myocardial Infarction. ${ }^{112}$ It is also able to increase inotropism and decreases fatigue of skeletal muscle. ${ }^{113}$ The metabolism of this benzodioxole bioactive compound (134) was studied in vitro using recombinant cytochrome P450 (CYP450) enzymes and rat liver microsomes. CYP1A2 is the main isoenzyme involved in LASSBio-294 metabolism, which performed the oxidative cleavage of the methylenedioxy bridge, in a classical $O$-dealkylation step, to furnish the catechol metabolite 135 (Figure 51). ${ }^{114}$ However, a different metabolite was identified in serum of dog treated orally with LASSBio-294. This metabolite (136) formed by oxidation of the sulfur atom of the thiophene ring, was also identified in metabolism studies using fungus Beauveria bassiana ATCC 7159 (Figure 51). ${ }^{115}$ 
<smiles>CCCCCCC(=O)OCCO</smiles>

LASSBio-294 (134)<smiles>O=C(N/N=C/c1cccs1)c1ccc(O)c(O)c1</smiles>

(135)<smiles></smiles>

(136)

Figure 51. Cardioactive benzodioxole derivative (134) and its metabolites 135 and 136

\section{Final remarks}

Combining the chemical versatility and the biophoric features, safrole (1) can be considered an extraordinary raw material for the synthesis of several and distinct bioactive compounds. However, the proposed molecular reasons for safrole's toxicity highlight the eminent toxicophoric profile of allylbenzyl subunit and the potential toxicophoric feature of benzodioxole framework.

Although benzodioxole is found in the structure of drugs like cinoxacin (5), tadalafil (6), paroxetine (30), teniposide (39), trabectedin (53) and stiripentol (62), the presence of this subunit in compounds of therapeutic interest anticipates the possibility of toxic effects or drug-drug interactions, through its ability to inhibit CYP450 isoenzymes. However, it is noteworthy that the toxicity of this subunit of safrole' structure may be considerably different when presented in the structure of more complex and functionalized molecules. Since the mechanism of action proposed for benzodioxole toxicity provides preliminary step of metabolic bioactivation, with cleavage of methylenedioxy bridge by a $O$ - dealkylation step to furnish the catechol metabolite, that would be oxidized into quinone or quinone-methyde, which are responsible for covalent binding to endogenous bionucleophiles. Nevertheless, is important to consider that the first step of this process will depend on the affinity of the molecule and not the affinity of the fragment (i.e. benzodioxole) by metabolic enzymes. On the other hand, the second step will depend on: the rate of catechol conjugation with phase II metabolic enzymes, its redox potential and the structural features (electronic and steric) of the eventual quinone metabolite. However, even for considered safety drugs, idiosyncratic responses to compounds containing this molecular fragment may occur and should not be overlooked.

\section{Acknowledgments}

The author would like to thank and congratulate LASSBio $^{\circledR}$ for the $20^{\text {th }}$ anniversary of its foundation. I also thank CNPq (BR), FAPERJ (BR) and INCT-INOFAR (BR, Grant CNPq 573.564/2008-6 and FAPERJ E-26/170.020/2008) for fellowship and financial support. 


\section{References}

${ }^{1}$ Yuncker, T. G. The Piperaceae of Brazil I: Piper-Group I, II, III, IV. Hoehnea 1972, 2, 19. [Link]

${ }^{2}$ Rizzini, C. T.; Mors, W. B.; Botânica econômica brasileira, 2a. ed. Âmbito Cultural: Rio de Janeiro, 1995 [Link]

${ }^{3}$ Marques, C. A. Importância econômica da família Lauraceae. Floresta e Ambiente, 2001, 8, 195 [Link]

${ }^{4}$ Rocha, S. F. R.; Ming, L. C. 1999. Piper hispidinervum: A sustainable source of safrole, p.479. In: J. Janick (ed) Perspectives on new crops and new uses. ASHS Press: Alexandria. [Link]

${ }^{5}$ Barbosa, Q. P. S.; Câmara, C. A. G.; Ramos, C. S.; Nascimento, D. C. O.; Lima-Filho, J. V.; Guimarães, E. F. Chemical composition, circadian rhythm and antibacterial activity of essential oils of piper divaricatum: a new source of safrole. Química Nova 2012, 35, 1806. [CrossRef]

${ }^{6}$ Cremasco, M. A.; Braga, N. P. Synthesis of piperonal from essential oil of long-pepper (Piper hispidinervium C. DC.). Acta Amazonica 2012, 42, 275. [CrossRef]

7 Torii, S.; Uneyama, K.; Ueda, K. An electrochemical procedure for a practical preparation of piperonal from isosafrole. The Journal of Organic Chemistry 1984, 49, 1830. [CrossRef]

${ }^{8}$ Barreiro, E. J.; Costa, P. R. R.; Coelho, F. A. S.; Farias, F. M. C. Prostaglandin Analogues. Part 2. Synthesis Of New Derivatives From Safrole Isolated From Sassafraz Oil. Journal of Chemical Research (M) 1985, 2301. [Link]

9 Carratù, B.; Federici, E.; Gallo, F. R.; Geraci, A.; Guidotti, M.; Multari, G.; Palazzino, G.; Sanzini, E. Plants and parts of plants used in food supplements: an approach to their safety assessments. Annali dell'Istituto Superiore di Sanita 2010, 46, 370. [PubMed]

10 European Commission, (2001). Opinion of the Scientific Committee on Food on the safety of the presence of safrole (1-allyl-3,4- methylenedioxy benzene) in flavorings and other food ingredients with flavoring properties. Available at <http://ec.europa.eu/food/fs/sc/scf/out116_ en.pdf>. Accessed: 28 July 2014.

${ }^{11}$ Swanson, A. B.; Chambliss, D. D.; Blomquist, J. C.; Miller, E. C.; Miller, J. A. The mutagenicities of safrole, estragole, eugenol, trans-anethole, and some of their known or possible metabolites for Salmonella typhimurium mutants. Mutation Research 1979, 60, 143. [CrossRef] [PubMed]

12 Homburger, F.; Boger, E. The carcinogenicity of essential oils, flavors, and spices: a review. Cancer Research 1968, 28, 2372. [PubMed]

${ }^{13}$ Opdyke, D. L. J. Fragrance raw materials monographs. Food and Cosmetics Toxicology 1982, 20, 825. [CrossRef] [PubMed]

${ }^{14}$ Rietjens, I. M. C. M.; Boersma, M. G.; van der Woude, H.; Jeurissen, S. M. F.; Schutte, M. E.; Alink, G. M. Flavonoids and alkenylbenzenes: mechanisms of mutagenic action and carcinogenic risk. Mutation Research 2005, 574, 124. [CrossRef][PubMed] 15 loannides, C.; Delaforge, M.; Parke, D. V. Safrole: Its metabolism, carcinogenicity and interactions with cytochrome P-450. Food and Cosmetics Toxicology 1981, 19, 657. [CrossRef] [PubMed]

16 Guenthner, T. M.; Luo, G. Investigation of the role of the $2^{\prime}, 3^{\prime}$-epoxidation pathway in the bioactivation and genotoxicity of dietary allylbenzene analogs. Toxicology 2001, 160, 47. [CrossRef] [PubMed]

17 Borchert, P.; Miller, J. A.; Miller, E. C.; Shires, T. K. 1'-Hydroxysafrole, a proximate carcinogenic metabolite of safrole in the rat and mouse. Cancer Research, 1973, 33, 590. [PubMed]

${ }^{18}$ Miller, J. A.; Miller, E. C. The metabolic activation and nucleic acid adducts of naturally-occurring carcinogens: recent results with ethyl carbamate and the spice flavors safrole and estragole. British Journal of Cancer 1983, 48, 1. [CrossRef] [PubMed] 
${ }^{19}$ Caldwell, J.; Chan, V. S. W.; Marshall, A. D.; Hasheminejad, G.; Bounds, S. V. J. 1'hydroxylation is the only metabolic pathway of simple alkylbenzenes involved in their genotoxicity. Toxicologist 1992, 12, 56.

${ }^{20}$ Boberg E. W.; Miller E. C.; Miller J. A.; Poland A.; Liem A. Strong evidence from studies with brachymorphic mice and pentachlorophenol that 1'-sulfoxysafrole is the major ultimate electrophilic and carcinogenic metabolite of 1'-hydroxysafrole in mouse live. Cancer Research 1983, 43, 5163. [PubMed]

${ }^{21}$ Chan, V. S. W.; Caldwell, J. Comparative induction of unscheduled DNA synthesis in cultured rat hepatocytes by allylbenzenes and their 1'-hydroxy metabolites. Food and Cosmetics Toxicology 1992, 30, 831. [CrossRef]

${ }^{22}$ Burkey, J. L.; Sauer, J-M.; McQueenb, C. A.; Sipes, I. G. Cytotoxicity and genotoxicity of methyleugenol and related congeners - a mechanism of activation for methyleugenol. Mutation Research 2000, 453, 25. [CrossRef] [PubMed]

${ }^{23}$ Fukuto, J. M.; Kumagai, Y.; Cho, A. K. Determination of the mechanism of demethylenation of (methylenedioxy)phenyl compounds by cytochrome P450 using deuterium isotope effects. Journal of Medicinal Chemistry 1991, 34, 2871. [CrossRef] [PubMed]

${ }^{24}$ OBrien, P. J. Molecular mechanisms of quinone cytotoxicity. Chemico-Biological Interactions 1991, 80, 1. [CrossRef] [PubMed]

${ }^{25}$ Bolton, J. L.; Acay, N. M.; Vukomanovic, V. Evidence that 4-allyl-o-quinones spontaneously rearrange to their more electrophilic quinone methides: potential bioactivation mechanism for the hepatocarcinogen safrole. Chemical Research in Toxicology 1994, 7, 443. [CrossRef] [PubMed]

${ }^{26}$ Jeurissen, S. M. F.; Punt, A.; Boersma, M. G.; Jan J. P. Bogaards, J. J. P.; Fiamegos, Y. C.; Schilter, B.; van Bladeren, P. J.; Nicole H. P. Cnubben, N. H. P.; Rietjens, I. M. C. M.
Human cytochrome p450 enzyme specificity for the bioactivation of estragole and related alkenylbenzenes. Chemical Research in Toxicology 2007, 20, 798. [CrossRef] [PubMed]

${ }^{27}$ Ueng, Y-F.; Hsieh, C-H.; Don, M-J.; Chi CW.; Ho, L-K. Identification of the main human cytochrome P450 enzymes involved in safrole 1'-hydroxylation. Chemical Research in Toxicology 2004, 17, 1151. [CrossRef] [PubMed]

${ }^{28}$ Clemens, S.; Barz, W. Cytochrome P450dependent methylenedioxy bridge formation in Cicer arietinum. Phytochemistry 1996, 41, 457. [CrossRef]

${ }^{29}$ Chapple, C. Molecular-genetic analysis of plant cytochrome p450-dependent monooxygenases. Annual Review of Plant Physiology and Plant Molecular Biology 1998, 49, 311. [CrossRef] [PubMed]

${ }^{30}$ Ikezawa, N.; Tanaka, M.; Nagayoshi, M.; Shinkyo, R.; Sakaki, T.; Inouye, K.; Sato, F. Molecular cloning and characterization of CYP719, a methylenedioxy bridge-forming enzyme that belongs to a novel P450 family, from cultured Coptis japonica cells. The Journal of Biological Chemistry 2003, 278, 38557. [CrossRef] [PubMed]

${ }^{31}$ Ikezawa, N.; Iwasa, K.; Sato, F. CYP719A subfamily of cytochrome P450 oxygenases and isoquinoline alkaloid biosynthesis in Eschscholzia californica. Plant Cell Reports 2009, 28, 123. [CrossRef] [ PubMed]

32 Díaz Chávez, M. L.; Rolf, M.; Gesell, A.; Kutchan, T. M. Characterization of two methylenedioxy bridge-forming cytochrome P450-dependent enzymes of alkaloid formation in the Mexican prickly poppy Argemone mexicana. Archives of Biochemistry and Biophysics 2011, 507, 186. [CrossRef] [PubMed]

${ }^{33}$ Nelson, D. R.; Ming, R.; Alam, M.; Schuler, M. A. Comparison of cytochrome P450 genes from six plant genomes. Tropical Plant Biology 2008, 1, 216. [Link]

${ }^{34}$ Franklin, M. R. The enzymic formation of methylenedioxyphenyl derivative exhibiting 
an isocyanide-like spectrum with reduced cytochrome P-450 in hepatic microsomes. Xenobiotica 1971, 1, 581. [CrossRef] [PubMed]

${ }^{35}$ Philpot, R. M.; Hodgson, E. A cytochrome P-450-piperonyl butoxide spectrum similar to that produced by ethyl isocyanide. Life Sciences 1971, 10, 503. [CrossRef] [PubMed]

${ }^{36}$ Murray, M. Mechanisms of inhibitory and regulatory effects of methylenedioxyphenyl compounds on cytochrome P450-dependent drug oxidation. Current Drug Metabolism 2000, 1, 67. [CrossRef] [PubMed]

${ }^{37}$ Mansuy, D.; Battioni, J. P.; Chottard, J. C.; Ullrich, V. Preparation of a porphyrin-ironcarbene model for the cytochrome P 450 complexes obtained upon metabolic oxidation of the insecticide synergists of the 1,3-benzodioxole series. Journal of the American Chemical Society 1979, 101, 3971. [CrossRef]

${ }^{38}$ Dickins, M.; Elcombe, C. R.; Maloney, S. J.; Netter, K. J.; Bridges, J. W. Further studies on the dissociation of the isosafrole metabolitecytochrome p-450 complex. Biochemical Pharmacology 1979, 28, 231. [CrossRef] [PubMed]

${ }^{39}$ Hara, Y.; Nakajima, M.; Miyamoto, K. I.; Yokoi, T. Inhibitory effects of psychotropic drugs on mexiletine metabolism in human liver microsomes: prediction of in vivo drug interactions. Xenobiotica 2005, 35, 549. [CrossRef] [PubMed]

${ }^{40}$ Beaumont, K. C.; Causey, A. G.; Coates, P. E.; Smith, D. A. Pharmacokinetics and metabolism of zamifenacin in mouse, rat, dog and man. Xenobiotica 1996, 26, 459. [CrossRef] [PubMed]

${ }^{41}$ Amacher, D. E.; Fasulo, L. M.; Charuel, C.; Comby, P.; Beaumont. K. In vitro toxicity of zamifenacin $(U K-76,654)$ and metabolites in primary hepatocyte cultures. Xenobiotica 1998, 28, 895. [CrossRef] [PubMed]

42 Ueng, Y-F.; Hsieh, C-H.; Don, M-J. Inhibition of human cytochrome P450 enzymes by the natural hepatotoxin safrole. Food and Chemical Toxicology 2005, 43, 707. [CrossRef] [PubMed]
${ }^{43}$ Scott, J. G. ; Foroozesh, M. ; Hopkins, N. E. ; Alefantis, T. G. ; Alworth, W. L. Inhibition of cytochrome P450 6D1 by alkynylarenes, methylenedioxyarenes, and other substituted aromatics. Pesticide Biochemistry and Physiology, 2000, 67, 63. [CrossRef]

${ }^{44}$ Siani, A. C.; Zoghbi, M. G. B.; Wolter, E. L. A.; Vencato, I. 5-Methoxyjusticidin A, a new arylnaphthalene lignan from Protium unifoliolatum. Journal of Natural Products 1998, 61, 796. [CrossRef] [PubMed]

${ }^{45}$ Kishore, P. H.; Reddy, M. V. B.; Gunasekar, D.; Murthy, M. M.; Caux, C.; Bodo, B. A New Coumestan from Tephrosia calophylla. Chemical and Pharmaceutical Bulletin 2003, 51, 194. [CrossRef] [PubMed]

${ }^{46}$ Simonsen, H. T.; Larsen, M. D.; Nielsen, M. W.; Adsersena, A.; Olsen, C. E.; Strasberg, D.; Smitt, U. W.; Jaroszewski, J. W. Methylenedioxy- and methoxyflavones from Melicope coodeana syn. Euodia simplex. Phytochemistry 2002, 60, 817. [CrossRef] [PubMed]

${ }^{47}$ Ono, E.; Nakai, M.; Fukui, Y.; Tomimori, N.; Fukuchi-Mizutani, M.; Saito, M.; Satake, H.; Tanaka, T.; Katsuta, M.; Umezawa, T.; Tanaka, $Y$. Formation of two methylenedioxy bridges by a Sesamum CYP81Q protein yielding a furofuran lignan, $(+)$-sesamin. Proceedings of the National Academy of Sciences 2006, 103, 10116. [CrossRef] [PubMed]

48 Samaiya, G. C.; Saxena, V. K. 3',4'Methylenedioxy-7-hydroxy-6-isopentenyl Flavone, a New Flavone from Fagopyrum cymosum. Journal of Natural Products 1989, 52, 1305. [CrossRef]

${ }^{49}$ Orlikova, B.; Menezes, J. C. J. M. D. S.; Ji, S.; Kamat, S. P.; Cavaleiro, J. A. S.; Diederich, M. Methylenedioxy flavonoids: assessment of cytotoxic and anti-cancer potential in human leukemia cells. European Journal of Medicinal Chemistry 2014, 84, 173. [CrossRef] [PubMed]

${ }^{50}$ Dewick, P. M.; Medicinal Natural Products. A Biosynthetic Approach, $2^{\text {nd }}$ ed., John Wiley \& Sons Ltd, 2002, chapter 4, p. 121-164 and chapter 6, p. 291-398. [Link] 
${ }^{51}$ O'Dwyer, P. J.; Alonso, M. T.; LeylandJones, B.; Marsoni, S. Teniposide: a review of 12 years of experience. Cancer Treatment Reports 1984, 68, 1455. [PubMed]

52 Pettit, G.; Singh, S. B. Isolation, structure, and synthesis of combretastatin A-2, A-3, and B-2. Canadian Journal of Chemistry 1987, 65, 2390. [CrossRef]

${ }^{53}$ Nicolussia, S.; Viveros-Paredes, J. M.; Gachet, M. S.; Rau, M.; Flores-Soto, M. E.; Blunder, M.; Gertsch, J. Guineensine is a novel inhibitor of endocannabinoid uptake showing cannabimimetic behavioral effects in BALB/C mice. Pharmacological Research 2014, 80, 52. [CrossRef] [PubMed]

${ }^{54}$ Mollataghi, A.; Hadi, A. H. A.; Awang, K.; Mohamad, J.; Litaudon, M.; Mukhtar, M. R. (+)-Kunstlerone, a new antioxidant neolignan from the Leaves of Beilschmiedia kunstleri gamble. Molecules 2011, 16, 6582. [CrossRef] [PubMed]

${ }^{55}$ Coy-Barrera, E. D.; Cuca-Suárez, L. E.; Sefkow, M. PAF-antagonistic bicyclo[3.2.1]octanoid neolignans from leaves of Ocotea macrophylla Kunth. (Lauraceae). Phytochemistry 2009, 70, 1309. [CrossRef] [PubMed]

${ }^{56}$ Wright, A. E.; Forleo, D. A.; Gunawardana, G. P.; Gunasekera, S. P.; Koehn, F. E.; McConnell, $\quad O$ J. Antitumor tetrahydroisoquinoline alkaloids from the colonial ascidian Ecteinascidia turbinate. The Journal of Organic Chemistry 1990, 55, 4508. [CrossRef]

${ }^{57}$ D'Incalci, M.; Galmarini, C. M. A review of trabectedin (ET-743): a unique mechanism of action. Molecular Cancer Therapeutics 2010, 9, 2157. [CrossRef] [PubMed]

${ }^{58}$ Cuevas, C.; Pérez, M.; Martín, M. J.; Chicharro, J. L.; Fernández-Rivas, C.; Flores, M.; Francesch, A.; Gallego, P.; Zarzuelo, M.; de La Calle, F.; García, J.; Polanco, C.; Rodríguez, I.; Manzanares, I. Synthesis of ecteinascidin ET-743 and phthalascidin Pt650 from cyanosafracin B. Organic Letters 2000, 2, 2545. [CrossRef] [PubMed]
${ }^{59}$ Costa, P. R. R. Safrol e eugenol: estudo da reatividade química e uso em síntese de produtos naturais biologicamente ativos e seus derivados. Química Nova 2000, 23, 357 [CrossRef]

${ }^{60}$ Lynch, J. K.; Freeman, J. C.; Judd, A. S.; lyengar, R.; Mulhern, M.; Zhao, G.; Napier, J. J.; Wodka, D.; Brodjian, S.; Dayton, B. D.; Falls, D.; Ogiela, C.; Reilly, R. M.; Campbell, T. J.; Polakowski, J. S.; Hernandez, L.; Marsh, K. C.; Shapiro, R.; Knourek-Segel, V.; Droz, B.; Bush, E.; Brune, M.; Preusser, L. C.; Fryer, R. M.; Reinhart, G. A.; Houseman, K.; Diaz, G.; Mikhail, A.; Limberis, J. T.; Sham, H. L.; Collins, C. A.; Kym, P. R. Optimization of chromone-2-carboxamide melanin concentrating hormone receptor 1 antagonists: assessment of potency, efficacy, and cardiovascular safety. Journal of Medicinal Chemistry 2006, 49, 6569. [CrossRef] [PubMed]

${ }^{61}$ Iyengar, R. R.; Lynch, J. K.; Mulhern, M. M.; Judd, A. S.; Freeman, J. C.; Gao, J.; Souers, A. J.; Zhao, G.; Wodka, D.; Doug Falls, H.; Brodjian, S.; Dayton, B. D.; Reilly, R. M.; Swanson, S.; Su, Z.; Martin, R. L.; Leitza, S. T.; Houseman, K. A.; Diaz, G.; Collins, C. A.; Sham, H. L.; Kym, P. R. An evaluation of 3,4methylenedioxy phenyl replacements in the aminopiperidine chromone class of $\mathrm{MCHr} 1$ antagonists. Bioorganic \& Medicinal Chemistry Letters 2007, 17, 874. [CrossRef] [PubMed]

62 Ruel, J.; Guitton, M. J.; Puel, J-L. Negative allosteric modulation of AMPA-preferring receptors by the selective isomer GYKI 53784 (LY303070), a specific non-competitive AMPA antagonist. CNS Drug Reviews 2002, 8, 235. [CrossRef] [PubMed]

${ }^{63}$ Wang, Y.; Konkoy , C. S.; Ilyin, V. I.; Vanover, K. E.; Carter, R. B.; Weber, E.; Keana, J. F. W.; Woodward, R. M.; Cai, S. X. Synthesis of 7,8-(methylenedioxy)-1-phenyl3,5-dihydro-4H-2, 3-benzodiazepin-4-ones as novel and potent noncompetitive AMPA receptor antagonists. Journal of Medicinal Chemistry 1998, 41, 2621. [CrossRef] [PubMed] 
${ }^{64}$ Raja, S. G. Endothelin receptor antagonists for pulmonary arterial hypertension: an overview. Cardiovascular Therapeutics 2010, 28, e65. [CrossRef] [PubMed]

${ }^{65}$ Galie, N.; Hoeper, M. M.; Gibbs, J. S. R. Simonneau, G. Liver toxicity of sitaxentan in pulmonary arterial hypertension. European Respiratory Journal 2011, 37, 475. [CrossRef] [PubMed]

${ }^{66}$ Jarvis, M. F.; Wessale, J. L.; Zhu, C. Z.; Lynch, J. J.; Dayton, B. D.; Calzadilla, S. V.; Padley, R. J.; Opgenorth, T. J.; Kowaluk, E. A. ABT-627, an endothelin ETA receptorselective antagonist, attenuates tactile allodynia in a diabetic rat model of neuropathic pain. European Journal of Pharmacology 2000, 388, 29. [CrossRef] [PubMed]

${ }^{67}$ Cullen, J. P.; Bell, D.; Kelso, E. J.; McDermott, B. J. Use of A-192621 to provide evidence for involvement of endothelin ETBreceptors in endothelin-1-mediated cardiomyocyte hypertrophy. European Journal of Pharmacology 2001, 417, 157. [CrossRef]

${ }^{68}$ Chiron, C. Stiripentol. Expert Opinion on Investigational Drugs 2005, 14, 905. [CrossRef] [PubMed]

69 Aboul-Enein, M. N.; El-Azzouny, A. A.; Attia, M. I.; Maklad, Y. A.; Amin, K. M.; Abdel-Rehim, M.; El-Behairy, M. F. Design and synthesis of novel stiripentol analogues as potential anticonvulsants. European Journal of Medicinal Chemistry 2012, 47, 360. [CrossRef] [PubMed]

${ }^{70}$ Li, Z-J.; Ren, H-Y.; Cui, M-C.; DeutherConrad, W.; Tang, R-K.; Steinbach, J.; Brust, P.; Liu, B-L.; Jia, H-M. Synthesis and biological evaluation of novel 4-benzylpiperazine ligands for sigma-1 receptor imaging. Bioorganic \& Medicinal Chemistry 2011, 19, 2911. [CrossRef] [PubMed]

${ }^{71}$ Pettit, G. R.; Anderson, C. R.; Herald, D. L.; Jung, M. K.; Lee, D. J.; Hamel, E.; Pettit, R. K. Antineoplastic agents. 487. Synthesis and biological evaluation of the antineoplastic agent 3,4-methylenedioxy-5,4'-dimethoxy-3'amino-Z-stilbene and derived amino acid amides. Journal of Medicinal Chemistry 2003, 46, 525. [CrossRef] [PubMed]

72 Wang, H-H.; Qiu, K-M.; Cui, H-E.; Yang, Y-S.; Yin-Luo; Xing, M.; Qiu, X-Y.; Bai, L-F.; Zhu, H-L. Synthesis, molecular docking and evaluation of thiazolyl-pyrazoline derivatives containing benzodioxole as potential anticancer agents. Bioorganic \& Medicinal Chemistry 2013, 21, 448. [CrossRef] [PubMed]

${ }^{73}$ Kurtzberg, L. S.; Roth, S.; Krumbholz, R.; Crawford, J.; Bormann, C.; Dunham, S.; Yao, M.; Rouleau, C.; Bagley, R. G.; Yu, X. J.; Wang, F.; Schmid, S. M.; Lavoie, E. J.; Teicher, B. A. Genz-644282, a novel non-camptothecin topoisomerase I inhibitor for cancer treatment. Clinical Cancer Research 2011, 17, 2777. [CrossRef] [PubMed]

${ }^{74}$ Chen, Y-F.; Lin, Y-C.; Huang, P-K.; Chan, HC.; Kuo, S-C.; Lee, K-H.; Huang, L-J. Design and synthesis of 6,7-methylenedioxy-4substituted phenylquinolin-2(1H)-one derivatives as novel anticancer agents that induce apoptosis with cell cycle arrest at G2/M phase. Bioorganic \& Medicinal Chemistry 2013, 21, 5064. [CrossRef] [PubMed]

${ }^{75}$ Belsches-Jablonski, A. P.;. Demory, M. L.; Parsons, J. T.; Parsons, S. J. The Src pathway as a therapeutic strategy. Drug Discovery Today Therapeutic Strategies, 2005, 2, 313. [CrossRef]

${ }^{76}$ Hennequin, L. F.; Allen, J.; Breed, J.; Curwen, J.; Fennell, M.; Green, T. P.; Lambert-van der Brempt, C.; Morgentin, R.; Norman, R. A.; Olivier, A.; Otterbein, L.; Plé, P. A.; Warin, N.; Costello, G. N-(5-chloro-1,3benzodioxol-4-yl)-7-[2-(4-methylpiperazin-1yl)ethoxy]-5- (tetrahydro-2H-pyran-4yloxy)quinazolin-4-amine, a novel, highly selective, orally available, dual-specific c$\mathrm{Src} / \mathrm{Abl}$ kinase inhibitor. Journal of Medicinal Chemistry 2006, 49, 6465. [CrossRef] [PubMed]

${ }^{77}$ Green, T. P.; Fennell, M.; Whittaker, R.; Curwen, J.; Jacobs, V.; Allen, J.; Logie, A.; Hargreaves, J.; Hickinson, D. M.; Wilkinson, R. W.; Elvin, P.; Boyer, B.; Carragher, N.; Plé, P. A.; Bermingham, A.; Holdgate, G. A.; Ward, 
W. H.; Hennequin, L. F.; Davies, B. R.; Costello, G. F. Preclinical anticancer activity of the potent, oral Src inhibitor AZD0530. Molecular Oncology 2009, 3, 248. [CrossRef] [PubMed]

78 Taipale, M.; Jarosz, D. F.; Lindquist, S. HSP90 at the hub of protein homeostasis: emerging mechanistic insights. Nature Reviews Molecular Cell Biology 2010, 11, 515. [CrossRef] [PubMed]

${ }^{79}$ Kim, S-H.; Bajji, A.; Tangallapally, R.; Markovitz, B.; Trovato, R.; Shenderovich, M.; Baichwal, V.; Bartel, P.; Cimbora, D.; McKinnon, R.; Robinson, R.; Papac, D.; Wettstein, D.; Carlson, R.; Yager, K. M. Discovery of (2S)-1-[4-(2-\{6-Amino-8-[(6bromo-1,3-benzodioxol-5-yl)sulfanyl]-9H-

purin-9-yl\}ethyl)piperidin-1-yl]-2-

hydroxypropan-1-one (MPC-3100), a PurineBased Hsp90 Inhibitor. Journal of Medicinal Chemistry 2012, 55, 7480. [CrossRef] [PubMed]

${ }^{80}$ Cedrón, J. C.; Gutiérrez, D.; Flores, N.; Ravelo, A. G.; Estévez-Braun, A. Synthesis and antiplasmodial activity of lycorine derivatives. Bioorganic \& Medicinal Chemistry 2010, 18, 4694. [CrossRef] [PubMed]

${ }^{81} \mathrm{He}$, Y.; Varadarajan,S.; Muñoz-Planillo, R.; Burberry, A.; Nakamura, Y.; Núñez, G. 3,4methylenedioxy- $\beta$-nitrostyrene inhibits NLRP3 inflammasome activation by blocking assembly of the inflammasome. The Journal of Chemical Biology 2014, 289, 1142. [CrossRef] [PubMed]

82 Latz, E.; Xiao, T. S.; Stutz, A. Activation and regulation of the inflammasomes. Nature Reviews Immunology 2013, 13, 397. [CrossRef] [PubMed]

${ }^{83}$ Vincent, S. H.; Painter, S. K.; Luffer-Atlas, D.; Karanam, B. V.; McGowan, E.; Cioffe, C.; Doss, G.; Chiu, S. H. Orally active inhibitors of human leukocyte elastase. II. Disposition of L694,458 in rats and rhesus monkeys. Drug Metabolism and Disposition 1997, 25, 932. [PubMed]

84 Harizi, H.; Corcuff, J. B.; Gualde, N. Arachidonic-acid-derived eicosanoids: roles in biology and immunopathology. Trends in Molecular Medicine 2008, 14, 461. [CrossRef] [PubMed]

${ }^{85}$ Barreiro, E. J.; Fraga, C. A. M. A utilização do safrol, principal componente químico do óleo de sassafráz, na síntese de substâncias bioativas na cascata do ácido araquidônico: antiinflamatórios, analgésicos e antitrombóticos. Química Nova 1999, 22, 744. [CrossRef]

${ }^{86}$ Costa, P. R. R.; Barros, P. R. V. R; Queiroz, W. M.; Lima, M. E. F.; Celestino, M. T.; Barreiro, E. J. Síntese de derivados do ácido 2,3-indolil-acético a partir do safrol. Química Nova 1982, 5, 112. [Link]

${ }^{87}$ Farias, F. M. C.; Barreiro, E. J.; Coelho, F. A. S.; Costa, P. R. R. Prostaglandin analogues; the synthesis of new prostanoids from natural safrole. Química Nova 1984, 7, 111. [Link]

88 Coelho, F. A. S.; Costa, P. R. E.; Farias, F. M. C.; Barreiro, E. J. Prostaglandin analogues; the synthesis of new thromboxane derivatives from natural safrole. Química Nova 1984, 7, 113. [Link]

${ }^{89}$ Barreiro, E. J.; Costa, P. R. R.; Coelho, F. A. S.; Farias, F. M. C. Prostaglandin Analogues. Part 2. Synthesis of New Derivatives from Safrole Isolated from Sassafraz Oil. Journal of Chemical Research (S) 1985, 220. [Link]

90 Farias, F. M. C.; Costa, P. R. R.; Barreiro, E. J. The synthesis of a new hybrid prostanoid from natural safrole. Química Nova 1987, 10, 154. [Link]

91 Pereira, E. F. R.; Pereira, N. A.; Lima, M. E. F.; Coelho, F. A. S.; Barreiro, E. J. Antiinflammatory properties of new bioisosteres of indomethacin synthesized from safrole which are sulindac analogues. Brazilian Journal Of Medical and Biological Research 1989, 22, 1415. [PubMed]

92 Barreiro, E. J.; Lima, M. E. F. The synthesis and anti-inflammatory properties of a new sulindac analogue synthesized from natural safrole. Journal of Pharmacological Sciences 1992, 81, 1219. [CrossRef] [PubMed] 
${ }^{93}$ Fraga, C. A. M.; Barreiro, E. J. The synthesis of a new benzothiazine derivative, related to oxicams, synthesized from natural safrole. Journal of Heterocyclic Chemistry 1992, 29, 1667. [CrossRef]

${ }^{94}$ Silva, E. F.; Barreiro, E. J. The synthesis and anti-inflammatory activity of 1-alkylisochroman-1-yl acetic acid derivatives. Journal of the Brazilian Chemical Society 1993, 4, 40. [CrossRef]

${ }^{95}$ Cabral, L. M.; Barreiro, E. J. The synthesis and analgesic properties of new spiroisochromanyl acid derivatives synthesized from natural safrole. Journal of Heterocyclic Chemistry 1995, 32, 959. [Link]

${ }^{96}$ Santos, M. R. L.; Barreiro, E. J.; Braz-Filho, R.; Miranda, A. L. P. The synthesis of new isochromanylacetylarylhydrazones designed as probable non-addictive analgesic agents. Journal of the Brazilian Chemical Society 1997, 8, 471. [CrossRef]

97 Zarghi, A; Arfaei, S. Selective COX-2 inhibitors: a review of their structure-activity relationships. Iranian Journal of Pharmaceutical Research 2011, 10, 655. [PubMed]

${ }^{98}$ Lages, A. S.; Silva, K. C. M.; Miranda, A. L. P.; Fraga, C.A. M.; Barreiro, E. J. Synthesis and pharmacological evaluation of new flosulide analogues, synthesized from natural safrole. Bioorganic \& Medicinal Chemistry 1998, 8, 183. [CrossRef] [PubMed]

${ }^{99}$ Lima, P. C.; Lima, L. M.; Da Silva, K. C. M.; Lédab, P. H. O.; Miranda, A. L. P.; Fraga, C. A. M.; Barreiro, E. J. Synthesis and analgesic activity of novel $\mathrm{N}$-acylarylhydrazones and isosters, derived from natural safrole. European Journal of Medicinal Chemistry 2000, 35, 187. [CrossRef] [PubMed]

100 Lima, L. M.; Amarante, E. G.; Miranda, A. L. P.; Fraga, C. A. M.; Barreiro, E. J. Synthesis and antinociceptive profile of novel acidic sulphonylhydrazone derivatives from natural safrole. Pharmacy and Pharmacology Communications 1999, 5, 673. [CrossRef]

101 Bezerra-Netto, H. J. C.; Lacerda, D. I.; Miranda, A. L. P.; Alves, H. M.; Barreiro, E. J.; Fraga, C. A. M. Design and synthesis of 3,4- methylenedioxy-6-

nitrophenoxyacetylhydrazone derivatives obtained from natural safrole: new leadagents with analgesic and antipyretic properties. Bioorganic \& Medicinal Chemistry 2006, 14, 7924. [CrossRef] [PubMed]

102 Duarte, C. D.; Tributino, J. L. M.; Lacerda, D. I.; Martins, M. V.; Alexandre-Moreira, M. S.; Dutra, F.; Bechara, E. J. H.; De-Paula, F. S.; Goulart, M. O.; Ferreira, J.; Calixto, J. B.; Nunes, M. P.; Bertho, A. L.; Miranda, A. L. P.; Barreiro, E. J.; Fraga, C. A. M. Synthesis, pharmacological evaluation and electrochemical studies of novel 6-nitro-3,4methylenedioxyphenyl- $\mathrm{N}$-acylhydrazone derivatives: Discovery of LASSBio-881, a new ligand of cannabinoid receptors. Bioorganic \& Medicinal Chemistry 2007, 15, 2421. [CrossRef] [PubMed]

${ }^{103}$ Halushka, P. V.; Mais, D. E.; Mayeux, P. R.; Morinelli, T. A. Thromboxane, prostaglandin and leukotriene receptors. Annual Review of Pharmacology and Toxicology 1989, 29, 213. [CrossRef] [PubMed]

${ }^{104}$ Lima, L. M.; Ormelli, C. B.; Brito, F. F.; Miranda, A. L.; Fraga, C. A.; Barreiro, E. J. Synthesis and antiplatelet evaluation of novel aryl-sulfonamide derivatives, from natural safrole. Pharmaceutica Acta Helvetiae 1999, 73, 281. [CrossRef] [PubMed]

105 Lima, L. M.; Ormelli, C. B.; Fraga, C. A. M.; Miranda, A. L. P.; Barreiro, E. J. New antithrombotic arylsulfonylthiosemicarbazide derivatives synthesized from natural safrole. Journal of the Brazilian Chemical Society 1999, 10, 421. [CrossRef]

${ }^{106}$ Reis, A. L. A.; Ormelli, C. B.; Miranda, A. P. M.; Fraga, C. A. M.; Barreiro, E. J. Studies on antiplatelet agents from natural safrole. II. Synthesis and pharmacological properties of novel functionalized oxime $O$-benzylether derivatives. Pharmaceutica Acta Helvetiae 1999, 74, 19. [CrossRef] [PubMed]

107 Lima, L. M.; Frattani, F.; dos Santos, J. L.; Castro, H. C.; Fraga, C. A. M.; Zingali, R. B.; Barreiro, E. J. Synthesis and anti-platelet activity of novel arylsulfonate--acylhydrazone 
derivatives, designed as antithrombotic candidates. European Journal of Medicinal Chemistry 2008, 43, 348. [CrossRef] [PubMed]

108 Lopes, R. O.; Romeiro, N. C.; Lima, C. K. F.; Silva, L. L.; Miranda, A. L. P.; Nascimento, P. G. B. D.; Cunha, F. Q.; Barreiro, E. J.; Lima, L. $M$. Docking, synthesis and pharmacological activity of novel urea-derivatives designed as p38 MAPK inhibitors. European Journal of Medicinal Chemistry 2012, 54, 264. [CrossRef] [PubMed]

${ }^{109}$ Brando Lima, A. C.; Machado, A. L.; Simon, P.; Cavalcante, M. M.; Rezende, D. C.; Sperandio da Silva, G. M.; Nascimento, P. G.; Quintas, L. E.; Cunha, F. Q.; Barreiro, E. J.; Lima, L. M.; Koatz, V. L. Anti-inflammatory effects of LASSBio-998, a new drug candidate designed to be a p38 MAPK inhibitor, in an experimental model of acute lung inflammation. Pharmacological Reports 2011, 63, 1029. [CrossRef]

110 Zapata-Sudo, G.; Lima, L. M.; Pereira, S. L.; Trachez, M. M.; da Costa, F. P.; Souza, B. J.; Monteiro, C. E.; Romeiro, N. C.; D'Andrea, E. ED.; Sudo, R. T.; Barreiro, E. J. Docking, synthesis and anti-diabetic activity of novel sulfonylhydrazone derivatives designed as PPAR-gamma agonists. Current Topics in Medicinal Chemistry 2012, 12, 2037. [CrossRef] [PubMed]

111 Romeiro, L. A. S.; Ferreira, M. S.; da Silva, L. L.; Castro, H. C.; Miranda, A. L.. P.; Silva, C. L.; Noël, F.; Nascimento, J. B.; Araújo, C. V.; Tibiriçá, E.; Barreiro, E. J.; Fraga, C. A. Discovery of LASSBio-772, a 1,3-benzodioxole $\mathrm{N}$-phenylpiperazine derivative with potent alpha 1A/D-Adrenergic receptor blocking properties. European Journal of Medicinal Chemistry 2011, 46, 3000. [CrossRef] [PubMed]

112 Costa, D. G.; Silva, J. S.; Kümmerle, A. E.; Sudo, R. T.; Landgraf, S. S.; Caruso-Neves, C.; Fraga, C. A. M.; Barreiro, E. J.; Zapata-Sudo, G. LASSBio-294, A compound with inotropic and lusitropic activity, decreases cardiac remodeling and improves $\mathrm{Ca}^{2}(+)$ influx into sarcoplasmic reticulum after myocardial infarction. American Journal of Hypertension 2010, 23, 1220. [PubMed]

${ }^{113}$ Gonzalez-Serratos, H.; Chang, R.; Pereira, E. F.; Castro, N. G.; Aracava, Y.; Melo, P. A.; Lima, P. C.; Fraga, C. A.; Barreiro, E. J.; Albuquerque, E.X. A novel thienylhydrazone, (2-thienylidene)3,4-

methylenedioxybenzoylhydrazine, increases inotropism and decreases fatigue of skeletal muscle. Journal of Pharmacology and Experimental Therapeutics 2001, 299, 558. [PubMed]

${ }^{114}$ Fraga, A. G.; Silva, L. L.; Fraga, C. A.; Barreiro, E. J. CYP1A2-mediated biotransformation of cardioactive 2thienylidene-3,4-

methylenedioxybenzoylhydrazine (LASSBio294) by rat liver microsomes and human recombinant CYP enzymes. European Journal of Medicinal Chemistry 2011, 46, 349. [CrossRef] [PubMed]

${ }^{115}$ Carneiro, E. O.; Andrade, C. H.; Braga, R. C.; Tôrres, A. C.; Alves, R. O.; Lião, L. M.; Fraga, C. A.; Barreiro, E. J.; de Oliveira, V. Structure-based prediction and biosynthesis of the major mammalian metabolite of the cardioactive prototype LASSBio-294. Bioorganic \& Medicinal Chemistry Letters 2010, 20, 3734. [CrossRef] [PubMed]

${ }^{116}$ Costa, P. R. R. Safrol e eugenol: estudo da reatividade química e uso em síntese de produtos naturais biologicamente ativos e seus derivados. Química Nova, 2000, 23, 357. [CrossRef]

${ }^{117}$ Moreira, D. R. M.; Leite, A. C. M.; Ferreira, P. M. P.; Costa, P. M.; Costa-Lotufo, L. V.; Moraes, M. O.; Brondani, D. J.; O Pessoa, $C$. Synthesis and antitumour evaluation of peptidyl-like derivatives containing the 1,3benzodioxole system. European Journal of Medicinal Chemistry 2007, 42, 351. [Crossref] [PubMed] 